\title{
What Moves the Stock and Bond Markets? A Variance Decomposition for Long-Term Asset Returns
}

\section{Citation}

Campbell, John Y., and John Ammer. 1993. What moves the stock and bond markets? A variance decomposition for long-term asset returns. Journal of Finance 48(1): 3-37.

\section{Published Version}

http://dx.doi.org/10.2307/2328880

\section{Permanent link}

http://nrs.harvard.edu/urn-3:HUL.InstRepos:3382857

\section{Terms of Use}

This article was downloaded from Harvard University's DASH repository, and is made available under the terms and conditions applicable to Other Posted Material, as set forth at http:// nrs.harvard.edu/urn-3:HUL.InstRepos:dash.current.terms-of-use\#LAA

\section{Share Your Story}

The Harvard community has made this article openly available. Please share how this access benefits you. Submit a story.

Accessibility 
NBER WORKING PAPER SERIES

WHAT MOVES THE STOCK AND BOND MARKETS?

A VARIANCE DECOMPOSITION FOR LONG-TERM ASSET RETURNS

John Y. CampbelI

John Ammer

Working Paper No. 3760

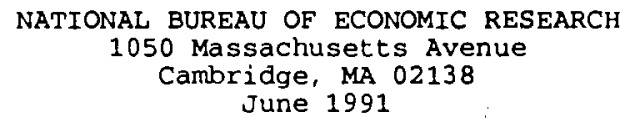

First draft, December 1990; this revision, June 1991. This paper was presented at the annual meeting of the American Finance Association, Washington DC, December 1990. We are grateful to Ben Bernanke and Robert Stambaugh for helpful coments, and to Rick Mishkin for assistance with the data. Campbell acknowledges financial support from the National Science Foundation and the Sloan Foundation. This paper is part of NBER's research program in Financial Markets and Monetary Economics. Any opinions expressed are those of the authors and not those of the National Bureau of Economic Research. 
NBER Working Paper $\$ 3760$

June 1991

WHAT MOVES THE STOCK AND BOND MARKETS?

A VARIANCE DECOMPOSITION FOR LONG-TERM ASSET RETURNS

\section{ABSTRACT}

This paper uses a log-linear asset pricing framework and a vector autoregressive model to break down movements in stock and bond returns into changes in expectations of future stock dividends, inflation, short-term real interest rates, and excess returns on stocks and bonds. In monthly postwar U.S. data, excess stock returns are found to be driven largely by news about future excess stock returns, while excess 10-year bond returns are driven largely by news about future inflation. Real interest rate changes have little impact on either stock or 10-year bond returns, although they do affect the short-term nominal interest rate and the slope of the term structure. These findings help to explain why postwar excess stock and bond returns have been almost uncorrelated.

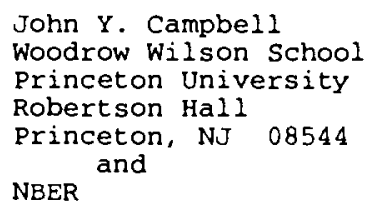

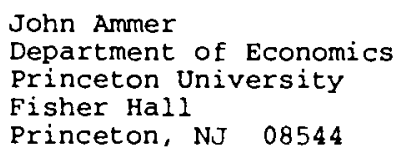




\section{Introduction}

Mainstream research in empirical asset pricing has traditionally treated the valiances and covariances of asset returns as being exogenous. The questions asked concern the optimal response of utility-maximizing agents to these variances and covariances, and the resulting equilibrium pattern of mean returns on securities.

Recently, however, a number of authors have cliallenged the finance profession to bring the second moments of asset returns within the set of plienomena to be explained. One of the first researchers to pose this challenge was Robert Shiller, who argued in the early 1980's that it is hard to account for the variance of stock returns using a model with constant discount rates. ${ }^{1}$ Richard Roll has issued a similar challenge in a recent Presidential Address to the American Finance Association (1988), saying that "The immaturity of our science is illustrated by the conspicuous lack of predictive content about some of its most intensely interesting phenomena, particularly changes in asset prices".

One straightforward way to meet this challenge is to regress asset price changes on contemporaneous news events. Roll (1988) does this for individual stocks and finds that less than $40 \%$ of the variance of price changes is typically explained by the regressions. Eugene Fama (1990a) has applied a similar methodology to the aggregate stock market. He finds that almost two-thirds of the variance of aggregate stock price movements can be accounted for by innovations in variables proxying for corporate cash flows and investors' discount rates. ${ }^{2}$ Other recent papers using this approach include Cutler, Poterba, and Summers (1989) and Stambaugh (1990).

The use of contemporaneous regressions to explain asset price variability is appealing because it is simple, and because it is an extension of the well-established event study methodology in finance. However there is a major conceptual difficulty with this approach. Suppose that innovations to a particular variable, say industrial production, are associated with stock market movements. This could reflect an association of industrial production with changing expectations of future cash flows, or an association with clianging discount rates (perhaps because both industrial production and stock prices are responding to interest rate movements). The contemporaneous regression approach cannot distinguish these possibilities, or tell us about their relative importance.

\footnotetext{
'This resenrch is reprinted and summarized in Shiller (1990).

${ }^{2}$ Fama uses leads of some varisbles as well as contemporaneous values. This is an informal way to allow for extra information that market participants may have about future macroeconomic de velopnnents.
} 
In this paper we use an alternative approach developed in Campbell and Shiller (1988a,b) and Campbell (1990a, 1991). Those papers study the stock market in isolation, whereas here we try to account for the variance of stock returns jointly with the variance of long-tern nominal bond returns and the covariance between stock and bond returns. We first express the innovation to a long-term asset returu as the sum of revisions in expectations of future real cash payments to investors, ancl revisious in expectations of future real returns on the asset. (Expected future returus are further broken down into expected future real interest rates and expected future excess returns on the long-term asset.) In general this asset pricing franework holds as a log-lincar approximation (Campbell and Shiller 1988a). However we provide an exact log-linear relation for the case in which the long-term asset is a zero-coupon bond.

We combine the asset pricing framework with a vector autoregression (VAR) in long-term asset returns, interest rates, inflation, and other information that helps to forecast these variables. We assume that the VAR adequately captures the information used by investors. From the VAR we can calculate revisions in multi-period forecasts of real returns and cash flows, and thus we can break asset returns into several components. In the case of stocks, the components are changing expectations of future real dividends, future real interest rates, and future excess returns on stocks. In the case of long-term nominal bonds, the components are changing expectations of future inflation rates (which determine the real value of the fixed nominal payment made at maturity), future real interest rates, and future excess returns on long bonds. The variances and covariances of these components constitute the variances of stock and bond returns, and the covariance between them.

This approach builds on the vast literature on forecasting long-term asset returus, interest rates, and inflation rates. Many recent papers have shown that dividend yields and short- and long-term interest rates have a modest degree of forecasting power for excess stock returns (Campbell 1987, 1990a, 1991, Campbell and Shiller 1958a, Cutler, Poterba, and Summers 1990, Fama and Scliwert 1977, Hodrick 1991, Keim and Stambaugh 1986). The forecastability of stock returns seems to increase witl the time interval over which returns are measured (Campbell and Shiller 1988b, Fama and French 1988b), altliough there is some dispute about the statistical properties of longhorizon forecasts in a finite sample (Nelson and Kim 1990, Ricliardson 1989, Ricliardson and Stock 1989). Other work has shown that the slope of the term structure of interest rates helps to forecast excess bond returns (Campbell and Shiller 1991, Fama 1984, 
Fama and Bliss 1987, Shiller, Canplell, and Schoenlioltz 1983). There is sone evidence that forecasts of excess bond and stock returns are correlated (Fama and Frencl 1989). At the same time, the term structure has considerable long-horizon forecasting power for nominal interest rate movements (Campbell and Sliller 1987, 1991, Fama and Bliss 1987), and for inflation rates (Fama 1990b, Misllkin 1990). In contrast with most of this research, our objective is not merely to forecast asset returns, but to derive the implications of our forecasts for the ex post variability of returns.

An important cliaracteristic of our approach is that we use a multivariate information set. Much recent work on the time series behavior of asset returns has concentrated on the autocorrelation function of returns (Conrad and Kaul 1988, Fama and French 1988a, Lo and MacKinlay 1988, Poterba and Summers 1988). But as we discuss below, it is possible for ex post returns to be driven largely by changing expectations of future returns, even if the autocorrelations of returns are all zero or very close to zero. Thus there can be a big payoff to using all relevant information for forecasting returns, and not merely the history of returns themselves.

The paper closest to ours is Shiller and Beltratti (1990). The main difference is that Shiller and Beltratti concentrate more on testing hypotheses that certain components are absent from returns. In addition we distinguish more separate components of returns than do Shiller and Beltratti, we use montlly rather than annual data, we concentrate on the postwar period, and we study zero-coupon bonds of various maturities while Shiller and Beltratti look at consols and other long-maturity coupon bonds.

The organization of the paper is as follows. Section 2 describes the asset pricing framework for stocks and bonds. Section 3 explains our data sources and VAR methodology. Section 4 presents empirical results for U.S. data over the period 1952-1987, and section 5 concludes. 


\section{Asset Prices, Expected Returns, and Unexpected Returns}

In this section we first use the log-linear approxinate asset pricing franework of Campbell and Shiller (1988a) to express unexpected excess stock returns as a function of news about future dividend growth rates, real interest rates, and excess stock returns. We develop the corresponding expression for nominal zero-coupon bonds, which holds exactly rather than as an approximation. We then show why asset prices are useful for forecasting long-horizon returns, and why lagged asset returns may not help to forecast returns even when expected returns vary through time. Finally, we express the unexpected bond return as a sum of returns on portfolios that are sensitive to the level (but not the slope) and the slope (but not the level) of the term structure. Returns on these level and slope portfolios can be decomposed in the same way as bond and stock returns.

\subsection{Expected and Unexpected Stock Returns}

The basic equation for stock returns relates the unexpected excess stock return in period $t+1$ to changes in rational expectations of future dividend growth, future real interest rates, and future excess stock returns. We write $e_{t+1}$ for the log excess return on a stock held from the end of period $t$ to the end of period $t+1$, relative to the return on short debt. ${ }^{3}$ We write $d_{t+1}$ for the $\log$ real dividend paid during period $t+1$, and $r_{t+1}$ for the $\log$ real interest rate from $t$ to $t+1$. Then the equation is

$$
c_{t+1}-E_{t} e_{t+1}=\left(E_{t+1}-E_{t}\right)\left\{\sum_{j=0}^{\infty} \rho^{j} \Delta d_{t+1+j}-\sum_{j=0}^{\infty} \rho^{j} r_{t+1+j}-\sum_{j=1}^{\infty} \rho^{j} e_{t+1+j}\right\} .
$$

Here $E_{t}$ denotes an expectation formed at the end of period $\mathrm{t}$, and $\Delta$ denotes a 1 period backward difference. The parameter $\rho$ comes out of the log-linear approxination procedure; it is a number a little smaller than one ( 0.9962 in our enpirical work).

Equation (2.1) is not a behavioral model; rather, it is a dynamic accounting identity that imposes internal consistency on expectations. If the unexpected excess stock return

\footnotetext{
${ }^{3}$ The excene relum can be defined in eilher real or nominal lerms. Since ettl is just the difference between ewo continuously compounded retums, the price defator canceb from $e_{1+1}$. 
is negative, then either expected future dividend growth must be lower, or expected future real stock returns must be ligher, or both. To see why, consider an asset with fixed dividends whose price falls. Its dividend yield is now higher; this will increase the asset return unless there is a further capital loss. Capital losses cannot continue forever, so at some point in the future the asset must have higher real returns. These may come either in the form of higher real interest rates, or in the form of higher excess returns on stock relative to short-term debt.

The discounting at rate $\rho$ in equation (2.1) means that an increase in stock returns expected in the distant future is associated with a smaller drop in today's stock price than is an increase in stock returns expected in the near future. To understand why this is, consider the arrival of news tliat stock returns will be higher ten periods from now. If the path of dividends is fixed, the stock price must drop to allow a rise ten periods from now. Most of the drop occurs today, but for nine periods there are smaller declines which are compensated by a higher dividend yield. These further declines reduce the size of the drop which is required today.

Formally, equation (2.1) follows from the log-linear "dividend-ratio model" of Campbell and Shiller (1988a). This model is an appropriate framework because it allows both expected returns and expected future cash flows to affect asset prices. The model is derived by taking a first-order Taylor approximation of the equation relating the log stock return to log stock prices and dividends. The approximate equation is solved forward, imposing a terminal condition that the log dividend-price ratio does not follow an explosive process. Details are given in Appendix A.

It will be convenient to simplify the notation in equation (2.1). Let us define $v_{e, t+1}$ to be the unexpected component of the excess stock return $e_{t+1}, \epsilon_{d, t+1}$ to be the term in equation (2.1) that represents news about cash flows, $\epsilon_{r, t+1}$ to be the term that represents news about real interest rates, and $\epsilon_{e, t+1}$ to be the term that represents news about future excess returns. Thus we use $v$ to denote an innovation or surprise in a variable, and we use the Greek letter corresponding to the variable's Roman symbol to denote the news components making up that surprise. The different news components are distinguished by the appropriate subscripts. Our notational conventions are summarized in Table 1. Then equation (2.1) can be rewritten as

$$
v_{e, t+1}=\epsilon_{d, t+1}-\epsilon_{r, t+1}-\epsilon_{e, t+1}
$$




\subsection{Expected and Unexpected Bond Returns}

The basic equation for bond returns has a form similar to the basic equation for stock returns. We define $x_{n, t+1}$ to be the log excess one-period return on an $n$-period zero-coupon bond held from time $t$ to time $t+1$. (At time $t+1$, the bond becomes an $(n-1)$-period bond.) We define $\pi_{t+1}$ to be the log one-period inflation rate from $t$ to $t+1$. Then we have

$x_{n, t+1}-E_{t} x_{n, t+1}=\left(E_{t+1}-E_{t}\right)\left\{-\sum_{i=1}^{n-1} \pi_{t+1+i}-\sum_{i=1}^{n-1} r_{t+1+i}-\sum_{i=1}^{n-1} x_{n-i, t+1+i}\right\}$.

This equation is derived in Appendix B. Like the stock decomposition (2.1) it is a dynamic accounting identity rather than a behavioral model, but unlike (2.1) it holds exactly rather than as an approximation. It says that unexpected excess bond returus must be associated either with decreases in expected inflation rates over the life of the bond, or with decreases in expected future real returns on the bond. The latter can take the form either of decreases in future real interest rates, or of decreases in future excess bond returns. ${ }^{4}$ Changes in expected inflation rates appear in (2.3) because they alter the expected real value of the fixed nominal payoff on the bond, so they can cause capital gains and losses even if expected real bond returns are constant.

In the literature on the term structure of interest rates, the "expectations theory of the term structure" implies that the third term on the right land side of (2.3) is always zero; the "Fisher hypothesis" implies that the second term is always zero. When both these hypotheses hold, then only the first term varies through time and clinging expected inflation is the only source of unexpected capital gains and losses on long bonds relative to short bonds.

Using the more compact notation summarized in Table $1,(2.3)$ becones

$$
v_{x, t+1}=-\xi_{\pi, t+1}-\xi_{r, t+1}-\xi_{x, t+1} .
$$

\footnotetext{
"Note that the maturity of the bond alurinks as time passes, whe televant expectations are for the returne on a bund that will have a maturity of $(n-i)$ at time $t+i$. Also note that the summation in the first two terms on the right hand side of (2.3) could atart at 0 rather than 1 , and the equation would remain valid. The two extro terins would cancel out because they add to the nominal interest rate, which is known at time 2.
} 


\subsection{Asset Prices, Yields, and Returns as Forecasting Variables}

Scveral authors have recently found that long-term asset prices can be surprisingly powerful forecasting variables. Prices are sonetimes used in raw form, but more commonly they are used as elements of asset yields or yield spreads. For example, Campbell and Shiller (1988a,b) and Fama and French (1988b) use dividend yields to forecast stock returns, while Campbell and Shiller (1991), Fama (1990b) and Mishkin (1990) use bond yield spreads to forecast future bond returns, interest rates and inflation rates. The forecasting power of asset price variables is particularly evident when forecasts are made over long horizons. The asset pricing framework described above can be used to interpret these findings.

The approximate log-linear asset pricing framework for stocks implies that the real stock price $p_{t}$ embodies investors' forecasts of future real dividends, real interest rates, and excess returns on stock. Appendix A shows that

$$
p_{i}=E_{t} \sum_{j=0}^{\infty} \rho^{j}\left[(1-\rho) d_{t+1+j}-r_{t+1+j}-e_{t+1+j}\right]
$$

where a constant term has been suppressed since it plays no role in our analysis. It is often argued that real dividends follow a time series process with a unit root (Kleidon 1986). Equation (2.5) shows that a unit root in real dividends will lcad to a unit root in stock prices; this will cause econometric problems if stock prices arc used to forccast stationary variables. In this case one might want to work with the log dividend-price ratio or dividend yield, which satisfies

$$
d_{t}-p_{t}=E_{t} \sum_{j=0}^{\infty} \rho^{j}\left[-\Delta d_{t+1+j}+r_{t+1+j}+\epsilon_{t+1+j}\right] .
$$

The log dividend yicld is stationary if dividend growth rates, real interest rates, and excess stock returns are all stationary. As we discuss further below, in our data set these conditions appear to be met.

Equation (2.6) helps to explain why the dividend-price ratio has forccasting power for excess stock returns at long horizons. The third term on the right hand side of 
(2.6) is approximately equal to the conditional expectation of the long-horizon excess return. ${ }^{5}$ Provided that the other two terms on the right $\mathrm{l}_{1}$ and side of (2.6) are not too variable, the dividend-price ratio should perform well as a proxy for the long-horizon expected excess return. More generally, if there is any variation in the expected excess return, the dividend-price ratio should liave some forecasting power. ${ }^{6}$

A similar point can be made for bonds, without the use of any log-linear approximation. In the case of bonds, it is conventional to begin by transforming nominal prices to yields to maturity. The nominal $\log$ yield to maturity, $y_{n, t}$, is ninus the nominal $\log$ bond price divided by $n$. Appendix B relates the nominal bond yield to expected future real bond returns and inflation rates:

$$
y_{n, t}=\left(\frac{1}{n}\right) E_{t} \sum_{i=0}^{n-1}\left[\pi_{t+1+i}+r_{t+1+i}+x_{n-i, t+1+i}\right]
$$

Inflation rates take the place of real dividends in the bond analysis. Just as with real dividends, it is often argued that inflation rates follow a nonstationary unit root process. In this case the nominal bond yield will also be nonstationary and one may want to work with a yield spread instead of the yield itself. The yield spread between the $n$ period nominal interest rate and the 1-period nominal interest rate, $s_{n, t} \equiv y_{n, t}-y_{1, t}$, can be written as

$$
s_{n, t}=\left(\frac{1}{n}\right) E_{t} \sum_{i=0}^{n-1}\left[(n-1-i)\left(\Delta \pi_{t+2+i}+\Delta r_{t+2+i}\right)+x_{n-i, t+1+i}\right] .
$$

The yield spread is stationary if excess bond returns, inflation changes, and real interest rate changes are stationary. In our data set these conditions appear to be met.

Equation (2.8) relates nominal yield spreads to expected future changes in infiation rates and real interest rates, and to expected excess returns on long bonds. The expectations theory of the term structure makes the third term on the right hand side

\footnotetext{
${ }^{3}$ Campbell and Shilker (19886) emplasize this point.

- This will fal only if the long-lorizon expected exccas retum is perfectly negatively correlated with some, other cortiponent of the dividand yield, and these two components have exactly the riglit variasces so that their variation cancels out of the dividend yietd.
} 
of (2.8) constant, while the Fisher lypotliesis makes the second term on the right hand side zero. These hypotheses are extrene. In general, the nominal yield spread will be a uscful proxy for expectations of all the terins on the right hand side. This helps to explain why yield spreads help to forecast long-lorizon movements in inflation and interest rates, as well as excess returns on long bonds. ${ }^{7}$

An alternative way to forecast asset returns is to use the history of asset returns themselves. This univariate approach was popular in the early empirical finance literature; more recently it has been used by Fama and French (1988a) and Potcrba and Sumners (1988), who emphasize that one should look at the entire autocorrelation function of returns. Specifically, there may be negative autocorrelation at low frequencies which makes long-horizon lagged returns better forecasters than short-horizon lagged returns. Poterba and Summers argue that "If market and fundamental values diverge, but beyond some range the differences arc eliminated by speculative forces, then stock prices will revert to their mean. Returns must be negatively serially correlated at some frequency if 'erroneous' market moves are eventually corrected" (pp.27-28).

Campbell (1991) uses the asset pricing framework developed above to clarify the circumstances under which univariate regressions will have forecasting power for returns. Cannpbell studies a simple example in which the expected stock return follows a first-order autoregressive process. He shows that persistent movements in expected returns have offsetting effects on the autocorrelations of realized returns. On the one hand, the positive autocorrelations of expected returns carry over to realized returns; on the other hand, the capital loss associated with an increase in tlic expected return creates negative autocorrelations in the realized return series. These offsetting effects make it possible that all the autocovariances of stock returns are zero, even when expected returns are variable and persistent. Contrary to the claim of Poterba and Summers, time-varying expected returns do not necessarily imply negative (or positive) autocorrelations at any frequency.

Of course, in practice it is unlikely that rcalized stock returns will have autocovariances that are all exactly zero. Campbell's exanple simply shows that autocovariances may be close to zero even when changing expected returns contribute a great deal to the ex post variability of returns. Thus lagged returns may be less effective than dividend yields and other price-based variables in forecasting future returns.

\footnotetext{
${ }^{T}$ Estrella and Hardouvelis (1991) and Stock and Watson (1990) show that yield spreads also help to forecast the leved of economic sctivity. Equation (2.8) should be laelplul in llinking about why this is so.
} 


\subsection{Level Portfolios and Slope Portfolios}

In studying the properties of bond returns, it is common to distinguislı between returns that are associated with changes in the general level of interest rates, and returns that are associated with changes in long-term interest rates relative to slortterm rates (shifts in the slope of the term structure). In fact, theoretical bond pricing models often assume that there are two "factors" driving interest rates which can be associated with shifts in the level and slope of the term structure.

Our variance decomposition approach is perfectly consistent with this way of thinking about bond returns. We now slow that the excess return on an $n$-period bond can be written as the sum of excess returns on two portfolios, a "level portfolio" of 2-period bills whose excess return $l_{n, l+l}$ is sensitive only to innovations in the level of slort-term nominal interest rates, and a "slope portfolio", long in $n$-period bonds and short in 2 period bills, whose excess return $m_{n, t+1}$ is sensitive only to changes in the yield spread between long rates and short rates. The returns on the level and slope portfolios can be broken into components in just the same way as excess bond and stock returns. These decompositions answer the questions "What moves the short-terin nominal interest rate?", and "What moves the slope of the term structure?", respectively.

The excess return on an $n$-period bond can trivially be written as

$$
x_{n, t+1}=l_{n, t+1}+m_{n, t+1}
$$

where the components $l_{n, t+1}$ and $m_{n, t+1}$ are defined by

$$
\begin{aligned}
l_{n, l+1} & \equiv(n-1) x_{2, l+1} \\
m_{n, l+1} & \equiv x_{n, t+1}-(n-1) x_{2, t+1} .
\end{aligned}
$$

It is straiglitforward to show that the unexpected return on the n-period bond is $-(n-1)$ times the innovation in next period's yicld on the bond, while the unexpected return on the level portfolio is $-(n-1)$ times the innovation in next period's short-term interest rate and the unexpected return on the slope portfolio is $-(n-1)$ 
times the innovation in next period's yield spread. It follows from this (or from equations (2.3) and (2.10)) that the level and slope portfolio returns can be decomposed as follows:

$$
\begin{aligned}
& l_{n, t+1}-E_{l} l_{n, t+1}=-(n-1)\left(E_{t+1}-E_{t}\right)\left[\pi_{l+2}+r_{t+2}\right] \\
& m_{n, t+1}-E_{l} m_{n, t+1}= \\
& -\left(E_{t+1}-E_{t}\right) \sum_{i=1}^{n-1}\left[(n-1-i)\left(\Delta \pi_{l+2+i}+\Delta r_{t+2+i}\right)+x_{n-i, t+1+i}\right]
\end{aligned}
$$

In our more compact notation, (2.11) becomes

$$
\begin{aligned}
& v_{l, l+1}=-\lambda_{\pi, l+1}-\lambda_{r, l+1}, \\
& v_{m, l+1}=-\mu_{\pi, l+1}-\mu_{r, l+1}-\mu_{x, l+1} .
\end{aligned}
$$

These equations say that level portfolio returns are driven by changing expectations of inflation and real interest rates one period ahcad. Slope portfolio returns are determined by changing expectations of longer-term changes in inflation and real interest rates between the next period ahead and the more distant future, and also by changing expectations of future excess returns on long-term bonds. In our empirical work, the distinction between these portfolios turns out to be important. Our variance decomposition for bond returns places little weight on news about future real interest rates, but real interest rate variability is important for both the level and slope portfolios considered separately. 


\section{Alternative Methods for Empirical Variance Decomposition}

In the previous section we have stated a number of identities relating innovations in long-term asset returns to revisions in investors' expectations of future dividends, real interest rates, inflation rates, and cxcess long-term asset returns. Our objective is to use these identities to estimate the relative importance of the different components for the historical behavior of asset returns.

In this section we first discuss sone conceptual difficulties with the decomposition of return variance when the components of returns are correlated with one another. We then address the question of how one can form empirical proxies for revisions in expectations. We discuss the contemporaneous regression approach to this problem before introducing our preferred vector autoregressive method.

\subsection{Variance Decomposition witl Correlated Components}

For concreteness, we consider the decomposition of excess stock returns. We begin with the identity (2.2), which we restate here:

$$
v_{e, t+1}=\epsilon_{d, t+1}-\epsilon_{r, t+1}-\epsilon_{e, t+1} \text {. }
$$

For the present we will assume that the components $\epsilon_{d, t+1}, \epsilon_{r, t+1}$, and $\epsilon_{e, t+1}$ are directly observable; below we discuss the difficulties that arise from the fact that the components are unobservable.

In general the components in (3.1) can be correlated with each other. This creates a conceptual diffculty in stating a variance decomposition for $v_{e, t+1}$. Trivially we have

$$
\begin{aligned}
& \operatorname{Var}\left(v_{e, t+1}\right)=\operatorname{Var}\left(\epsilon_{d, t+1}\right)+\operatorname{Var}\left(\epsilon_{r, t+1}\right)+\operatorname{Var}\left(\epsilon_{e, t+1}\right) \\
& -2 \operatorname{Cov}\left(\epsilon_{d, t+1}, \epsilon_{r, t+1}\right)-2 \operatorname{Cov}\left(\epsilon_{d, t+1}, \epsilon_{e, t+1}\right)+2 \operatorname{Cov}\left(\epsilon_{r, t+1}, \epsilon_{e, t+1}\right) .
\end{aligned}
$$

One way to state a variance decomposition is simply to report the six numbers on the right hand side of (3.2), and we do this in our empirical work below. A number like 
$\operatorname{Var}\left(\epsilon_{d, l+1}\right)$ answers the question, "What woukl the variance of stock returns be if the process for stock dividends remained unclianged, but interest rates and expected excess stock returns became constant?". Whether this question is meaningful depends on the context. In an exchange economy, for example, stock dividends are nodelled as an exogenous endowment while interest rates and expected excess stock returns depend on the dividend process and on the risk aversion of a representative agent. In such an economy one could imagine reducing the risk aversion of the representative agent to zero, while leaving the endowment process unchanged. Tle effect of this would be to change the variance of stock returns to $\operatorname{Var}\left(\epsilon_{d, t+1}\right)$.

Alternatively, one may want to transform the components in (3.1) so that they are orthogonal to one another. $\operatorname{Var}\left(v_{e, t+1}\right)$ can then be written as a sum of variances of the orthogonalized components. One siniple and popular way to orthogonalize components is to order them and then apply a Cholesky decomposition. The variance of the first component in such an ordering is given by the variance of the fitted value in a sinple regression of $v_{e, t+1}$ on that component.

It is tempting to think that a component will have the largest share of variance when it is given first place in the ordering, in other words that the $R^{2}$ statistic of a simple regression of $v_{e, t+1}$ on a component will be an upper bound on the variance share of that component. Unfortunately this is incorrect. It is possible for a component to have a larger share of variance when it is placed lower in the ordering. To see this, note that if one component is negatively correlated with the others then it can be uncorrelated with the sum of the components. This component will get a zero share of variance when it is ordered first, but in general it will get a nonzero share when it is given a lower place in the ordering. ${ }^{8}$ Despite this difficulty of interpretation, a popular measure of the importance of a component is the $R^{2}$ statistic from a simple regression on that component. Accordingly we report this measure in our empirical work below.

Although correlation among components leads to ambiguity in the notion of a variance decomposition, this does not mean that the decomposition summarized by (3.1) and (3.2) is uninteresting when the components are correlated. The observation that the various components of an asset return are higlily correlated may itself be an important stylized fact.

\footnotetext{
Below we ahow that this is not just a theoretical possibility, lut oecure in wome of our asert return decompositione. For similar resoons the sum of the $R^{2}$ statistics from simple regressions on all the individual components may be either greater or lese than one, which would be the $R^{2}$ from a multiple regresion on the components.
} 


\subsection{The Contemporaneous Regression Approach}

In practice the expectational revisions in equation (3.1) are not directly observable. Cutler, Poterba, and Summers (1989), Fama (1990a), and Stanbaugh (1990) lave used contemporaneous regressions to deal with this problem. As we noted above, a popular measure of the importance of a particular component is the variance of the fitted value obtained when $v_{e, t+1}$ is regressed on that component. The contenuporaneous regression approach uses instead a vector of explanatory variables $w_{t+1}$ that proxies for the unobserved component. For concreteness, assume that $w_{t+1}$ is supposed to be a proxy for $\epsilon_{d, t+1}$. The following ordinary least squares (OLS) regression is run:

$$
v_{e, t+1}=\beta^{\prime} w_{t+1}+\eta_{t+1} \text {. }
$$

Then the variance of the fitted value of (3.3) is taken as a proxy for the variance of the fitted value of a regression of $v_{e, t+1}$ on $\epsilon_{d, t+1}$. The condition for this to be valid, of course, is

$$
\operatorname{Var}\left(E\left[v_{e, t+1} \mid w_{t+1}\right]\right)=\operatorname{Var}\left(E\left[v_{e, t+1} \mid \epsilon_{d, t+1}\right]\right)
$$

A sufficient condition for (3.4) to hold is that

$$
E\left[v_{e, t+1} \mid w_{\ell+1}\right]=E\left[v_{e, t+1} \mid \epsilon_{d, t+1}\right]
$$

Equation (3.5) is of course not necessary for (3.4), but we focus on this condition bccause it is hard to construct plausible examples in which (3.5) fails but (3.4) holds (other than by an unlikely coincidence). The condition (3.5) is in fact a fairly striugent one. To see this, note that (3.5) is not necessarily satisfied even if the vector $w_{t+1}$ is a perfect proxy for $\epsilon_{d, t+1}$ in the sense that $\epsilon_{d, t+1}$ can be written as a linear combination of the variables in $w_{t+1}$ :

$$
\begin{gathered}
\epsilon_{\mathrm{d}, t+1}=\theta^{\prime} w_{t+1}, \\
-14-
\end{gathered}
$$


for some vector $\theta$. Even when (3.6) liolds, it could be the case that the other components of $v_{e, t+1}$ can also be written as linear combinations of the variables in $u^{\prime} t+1$. For this or other reasons the vector $w_{l+1}$ may contain more information about $v_{e, l+1}$ than does the single component $\epsilon_{d, t+1}{ }^{9}$

Finally, we note that the contemporaneous regression approach can at best provide an estimate of the share of variance attributed to a component when it is ordered first in a process of sequential orthogonalization. This is not even an upper bound on the share of variance that ean be attributed to the component, because other positions in the ordering might give the component a larger share of variance. Thus the infornation that can be obtained from the contemporaneous regression approach is quite linited.

\subsection{The Vector Autoregressive Approach}

The vector autoregressive (VAR) approach is more ambitious than the contemporaneous regression approach in that it seeks to use the time-series structure of the problem to identify revisions in expectations. The VAR approach postulates that the unobserved components of returns can be written as linear combinations of innovations to observable variables: that is, equations like (3.6) hold for each of the components of returns. The coefficients in these linear combinations are identified by using a timeseries model to construct forecasts of the discounted value of future dividends, real interest rates, excess returns, and so forth. Revisions in these forecasts are then used as proxies for revisions in investors' expectations. This approach must confront two problems. First, the relevant expectations are of variables that are realized only over very long periods of time. (In the case of stocks, in fact, the expectations concern the infinitc future.) Second, investors may have information that is not available to us.

We handle the first problem by using a VAR model to calculate multi-period expectations. In effect, we use the short-run behavior of the variables to impute the long-run behavior. This procedure seems to have better finite-sample properties than direct regression methods with long-horizon variables, although of course it is necessary to assume that the VAR adequately captures the dynamics of the data. ${ }^{10}$

\footnotetext{
${ }^{9}$ Note that even when (3.5) and (3.6) hold, the OLS regression coefficients $\beta$ in (3.3) will not generally equal the parameters $\theta$ in (3.6). Equality of $\beta$ and $\theta$ would require in sddition that $\epsilon_{d, t+1}$ be orthogonal to the other components of $v_{c, i+1}$.

"io VARe are used by Campbell and Shiller (1987, 1988a,b) and Kandel and Stambaugh (1988). Fams and French $(1988 \mathrm{a}, \mathrm{b})$ pionected the use of long-horizon regrosions. The finice-sample properties of auch regressions are investigated by Riclurdson and Stodk (1989) and Hodrick (1991); liodrick explicitly compares them with vAR procedures. Campbell (1991) also unkertakes a Monte Carlo study of the properties of VAR variance decompositions.
} 
The second problem is nore difficult. In general there is no way to rule out the possibility that investors may have information, omitted from our VAR, which affects the decomposition of variance. A special case where investors' superior information causes no problem occurs when only one component of an asset price is tine-varying. In this case the asset price itself summarizes all the information investors liave about that component (Campbell and Sliller 1987). Thus if one is interested in testing the hypothesis that expected real interest rates and excess returns on long bonds are constant, this can be done using a VAR that includes the long bond yield or yield spread; under the null hypothesis the yield varies only because expected inflation varies, so it embodies all the relevant information about inflation that investors possess. When several components of an asset price are variable, however, the asset price will be an imperfect proxy for investors' information about any one component. In this case the VAR results must be interpreted more cautiously, as giving a variance decomposition conditional on whatever information is included in the system. In practice it seems likely that the VAR results will tend to overstate the importance of whiclever component is treated as a residual, but the sign of the bias will depend on the covariances between omitted and included variables. ${ }^{11}$

The VAR approach begins by defining a vector of state variables that help to measure or forecast excess returns. These variables are chosen to be stationary, and for notational convenience we treat them as having zero means. (In our empirical work we remove sample means from all variablès before estimating the VAR process.)

In order to measure excess returns and their components, our state vector must include at least the excess stock return, the real interest rate, the change in the nominal interest rate, and the long-short yield spread. In addition we use other variables that lave been shown to forecast excess bond and stock returns, real interest rates, and inflation rates. These variables are the dividend-price ratio, the 2-period yield spread, and the "relative bill rate". The relative bill rate, which is given further motivation below, is defined as the level of the short rate relative to a l-year backwards moving average of short rates, or equivalently as a triangular 1-year moving average of chasges in short rates. We use the notation $r b_{t}$ for the rclative bill rate, where

\footnotetext{
11 This potential problem of omitted information bias is of course shated by the contemporatieous regression approacl. 


$$
r b_{l} \equiv y_{1 t}-\left(\frac{1}{12}\right) \sum_{i=1}^{12} y_{1, t-i}=\sum_{i=0}^{12}\left(1-\frac{i}{12}\right) \Delta y_{1, t-i}
$$

Writing $z_{t}$ for the state vector and making the relative bill rate the last element, we lave

$$
z_{t}=\left\lfloor e_{t}, r_{t}, \Delta y_{1, t}, s_{n, t}, d_{t}-p_{t}, s_{2, l}, r b_{t}\right]^{\prime}
$$

Next we assume that the state vector follows a first-order VAR process:

$$
z_{l+1}=A z_{l}+w_{t+1}
$$

The matrix $A$ is the coefficient matrix of the VAR, and $w_{l}$ is the error vector. The assumption that the VAR is first-order is not restrictive; higher-order VAR models are handled by augmenting the state vector and reinterpreting $A$ as the companion matrix of the system. We also define vectors $e 1$ through $e 4$ as the four columns of a $4 \times 4$ identity matrix. The vector $e i$ is used to pick out the $i$ 'th element of the state vector.

Innovations to excess returns can now be obtained directly from the VAR error vector. We have $v_{e, l+1}=e 1^{\prime} w_{l+1}$ simply from the fact that $e_{t+1}$ is the first element of the state vector. The remaining innovations satisfy $v_{x, t+1}=-(n-1)\left(e 3^{\prime}+e 4^{\prime}\right) w_{t+1}$, $v_{l, t+1}=-(n-1) e 3^{\prime} w_{t+1}$, and $v_{m, t+1}=-(n-1) e 4^{\prime} w_{t+1}$. These expressions follow from the facts that the unexpected slope portfolio return is $-(n-1)$ times the innovation in the yield spread, the unexpected level portfolio return is $-(n-1)$ times the innovation in the short-term nominal interest rate, and the unexpected bond portfolio return is the sum of the unexpected slope and level portfolio returns. ${ }^{12}$ To obtain VAR estimates of revisions in long-horizon expectations, we use the fact that

$$
\left(E_{t+1}-E_{t}\right) z_{t+1+j}=A^{j} w_{t+1} .
$$

\footnotetext{
12 These formulas use the fact that the innovation in the level of the short rate is the same ax the innovation in the change of the short rate, since investors know the lagged short rate level beforehand. Also we ignore the distinction between $s_{n, t}$ and $s_{n-1,1}$. This introduces an approxinustion ertor that is very small when $n$ is large. 
This can be used to calculate each of the components of portfolio returns as a linear combination of the elements of the shock vector $w_{t+1}$.

For stock returns, we obtain the conponents $\epsilon_{e}$ and $\epsilon_{r}$ by forecasting excess stock returns and real interest rates respectively, while the remaining component $\epsilon_{d}$ is obtained from (2.2) as a residual. We give details of this procedure, which follows Canpbell (1990a, 1991), in Appendix C. One could instead include diviclend growth rates in the vector $z_{\boldsymbol{t}}$, leaving some other term to be the residual. However this would have two important disadvantages. First, monthly dividends display seasonal variation, which would need to be handled as part of the forecasting procedure. Second, there is some doubt as to whether dividends follow a linear time-series model with constant coeffcients. ${ }^{13}$

For bond returns, we first note that the change in inflation can be obtained from the elements of the state vector as $\Delta \pi_{t+1}=\Delta y_{1, t}-\Delta r_{t+1}$, so the innovation in the change in inflation and the innovation in the ex post real interest rate both equal $-e 2^{\prime} w_{t+1}$. One component of the excess bond return is a sum of revisions in expected inflation levels, but this can be rewritten as a weighted sum of revisions in expected inflation changes. We obtain inflation and real interest rate components by direct forecasting, leaving the revision in expected excess returns as the residual. This choice of residual is forced on us because we cannot directly measure the sequence of excess returns on the bond as its maturity shrinks over its remaining life. The components of slope and level portfolio returns are calculated in the analogous manner to the components of bond returns. The formulas for these components are given in Appendix $\mathrm{C}$.

The one remaining issue to address is how we calculate standard errors for statistics such as the variance of a particular component of returns. Our approach is to treat the VAR coefficients, and the elements of the variance-covariance matrix of VAR innovations, as parameters to be jointly estimated by Generalized Method of Moments (Hansen 1982). The GMM parameter estimates are numerically identical to standard OLS estimates, but GMM delivers a heteroskedasticity-consistent variance-covariance matrix for the entire set of parameters (White 10S4). Call the entire set of parameters $\gamma$, and the variance-covariance matrix $V$. Consider a statistic such as the variance of

\footnotetext{
13 The Modigliani-Miller propositions on the irtelevance of dividend policy give us no theoretical reason to expect managers to pursuc any particular dividend policy. Solne have argied that this underiunes empirical work tliat applies standard time-series metliods to dividends. Lehmann (1901), for example, says that "Tlie conventional practice of asauming a particular dividend poticy and computing its present value is fralight with hazard.... There is substantial reason to belicve that any assumed dividend policy is misspecified since managers have no obvious incentive to adopt or majntain a consistent dividend policy." (p.1). Whatever the merits of Lehmann's argument, it does not apply here since our approach naes no information on the timing of dividend payments as opposed to their present value.
} 
new's about future excess stock returns relative to the variance of unexpected stock returns. This can be written as a noulinear function $f(\gamma)$ of the parameter vector $\gamma$. Then we estimate the standard error for the statistic in standard fashion as $\sqrt{f_{\gamma}(\gamma)^{\prime} V f_{\gamma}(\gamma)}$. 


\section{An Application to Postwar U.S. Data}

\subsection{Data and Sample Period}

We now apply our methods to postwar U.S. data on stock and bond returns. Our stock index is the value-weighted index of stocks traded on the NYSE and AMEX, as calculated by the Center for Research in Security Prices (CRSP) at the University of Chicago. We measure the dividend yield on the index in a standard fashion, taking total dividends paid over the previous year relative to the current stock price.

For nominal interest rates, we use McCulloch's (1990) data set on zero-coupon yields implied by the yield curve for U.S. Treasury securities. At maturities beyond one year, U.S. Treasury securities pay coupons so $\mathrm{McC}$ Culloch uses a cubic spline method to calculate an implied zero-coupon yield curve. The McCulloch data are available at the beginning of each month from 1947:1-1987:3, but we start our sample in 1952:1 in order to avoid the period before the 1951 Treasury-Fed Accord. We set $n$, the maturity of our long bond, equal to 10 years (120 months) as this is the longest maturity that is available throughout the sample period. ${ }^{14}$

Our final piece of data is a price index for deflating nominal asset returns. We use the Consumer Price Index, adjusted before 1983 to reflect the improved treatment of housing costs that is used in the official index only after 1983.

Throughout the paper we report results for the full sample period 1952:1-1987:2, as well as for subsamples 1952:1-1979:9, 1952:1-1972:12, and 1973:1-1987:2. The first of these subsamples is chosen to exclude the period after the change in Federal Reserve operating procedures in October 1979. The level and volutility of interest rates increased considerably during the 1979-82 period, and it may be unreasonable to impose a constant linear time-series model on the pre- and post-1979 data together. The second subsample is chosen because it has been argued (Fama 1975) that the real interest rate was constant during the 1950's and 1960's; this would imply that all movements in nominal interest rates during this period were due to changing expectations of future inflation (and perhaps term premiums on longer-maturity bonds). The third subsample is the complement of the second subsample.

Table 2 reports some basic summary statistics about the second moments of excess

\footnotetext{
${ }^{14}$ Campbell and Shiller (1991) also use the McCulloch data The main alternative zero-eoupon yield series is due to Eugene Fama and Robert Bliss and is available from CRSP. This altermative has the advaninge that it is availabie up to the present, but the disadvantage that the lougest maturity is five years.
} 
returns on stocks, 10-year bonds, the level portfolio (2-montl bills), and the slope portfolio (long in 10-year bonds, short in 2-montl bills). All excess returns are measured montlyly over the return on a 1-montl Treasury bill. For each sample period we report variances and covariances (on and below the diagonal) and correlations (in bold face above the diagonal).

The main results in Table 2 are as follows. Looking first at the variances of excess returns, we see that stock returns are more volatile than 10 -year bond returns but the difference in variance is much larger in the early part of the sample. In 1952-72, the stock variance is about 4 times as large as the bond variance, whereas in 1973-87 the difference in variance is less than $10 \%$. It is also noteworthy that both the level and slope portfolios have higher variances than 10-year bonds; below we interpret this fact.

As for the correlations, the most striking feature of Table 2 is the very low correlation between excess returns on stocks and bonds. Conventional wisdom is that long-term asset prices move (or should move) together, but the monthly correlation between stock and bond returns never exceeds 0.075 in any sample. The correlations between stock returns on the one hand and level and slope portfolio returns on the other are also very close to zero. However the level and slope portfolio returns have a very strong tendency to move in opposite directions, with correlations lying between -0.85 and -0.90 in every sample. This reflects the fact that long-term interest rates are smoother than short-term rates, so an increase in short-term rates (a negative return on the level portfolio) tends to be associated with a decline in the yield spread (a positive return on the slope portfolio). The negative correlation between level and slope portfolios also explains why these portfolios each have higher variances than the bond portfolio, which is their sum.

The next step in our analysis is to run the VAR system described in the previous section. This system includes seven variables: the excess stock return, real interest rate, change in the nominal 1-month interest rate, and 10 year-1 month yield spread, which are needed to measure returns and their components; and the dividend-price ratio, 2 month-1 inonth yield spread, and relative bill rate, which are useful forecasting wriables. The main variable that may need some discussion is the relative bill rate. This is defined to be the current 1-nonth bill rate, less a backwards 1-year moving average of bill rates. Equivalently, it can be described as a triangular 1-year moving average of past changes in bill rates. The relative bill rate helps to capture some of the longer-run dynamics of changes in interest rates without introducing long lags, and 
hence a large number of paraneter's, into the VAR systenn. ${ }^{15}$

All the variables in the VAR system appear to be stationary in our sample period. Dickey-Fuller tests and augmented Dickey-Fuller tests with 4 lags reject the unit root hy'pothesis at the $5 \%$ level or better for each series included in the VAR. ${ }^{16}$

The number of variables in the VAR increases very rapidly with the lag length, so there is some danger of overfitting when a high-order VAR is used. For this reason we report results from a parsimonious first-order VAR in the full sample and all subsamples. We also give results from a third-order VAR estimated over the full sample, to show that our findings are robust to VAR lag length. ${ }^{17}$

\subsection{Variance Decompositions for Excess Bond and Stock Returns}

In Tables 3 and 4 we report the variance decompositions implied by the VAR for excess stock and bond returns, respectively. The first row of each table shows the $R^{2}$ when the VAR is used to forecast the monthly excess return on stocks or bonds, along with the joint significance level of the forecasting variables. Then the tables report the variances and covariances of the different components of the portfolio returns. These are normalized by the variance of the return innovation itself so the numbers reported are shares that add up to one. Finally the tables show the implied $R^{2}$ statistics that would be obtained in simple regrcssions of the unexpected excess return on each of the estimated components. As discussed above, these $R^{2}$ statistics are alternative measures of the importance of components. The variance and covariance shares and implied $R^{2}$ statistics of the components are reported with asymptotic standard errors, reflecting the fact that the components are not directly observed but are estimated from a VAR system.

Table 3 gives a variance decomposition for excess stock returns, similar to the one reported in Campbell (1991). The $R^{2}$ for forecasting excess stock returns at a monthly frequency is quite modest: just over $5 \%$ for the full sample, although it is somewhat

\footnotetext{
${ }^{13}$ The relative bill rate is also used by Canpbell (1990a, 1991) and Hodrick (1991).

${ }^{16}$ Barsky and DeLong (1989) argue that llie dividend growth rate may have anit root, which would put a unit root in the dividend-price ratio. Ilowever there is very little direct evidence for this proposition: Barsky and DeLong argue for it on the grounds that unit root tests may falsciy reject the null hypothesis in finite samples. Here we use unit root testa to indicate whether stationary anyniptutic distributionn are likely to be a good spproximation to the finite-sample distributions of VAR coefficients and test statistios.

17 Over the full sample, a Widd test for joiru significance of the secoind lag variables when these are ardded to the firstorder VAR provides strong eviderce tliat a second lag shoukf be included. There is weaker evidence for a third lag; the third lag variables are jointly significant at the $5 \%$ ievel only in the forecasting equation for tlie dividesid-price ratio. We also calcilated variance decompositions for a six. Ing VAR, whicli were similar to those reported.
} 
higher in the subsamples. ${ }^{18}$ The joint significance of the forecasting variables is $0.1 \%$ in the full sample, and less than $0.1 \%$ in the earlier subsamples. In the $1973-87$ period the forecasting variables narrowly fail to be significant at the $10 \%$ level.

Despite the modest degree of forecasting power for stock returns, the full sample variance decomposition attributes less than $15 \%$ of the variance of stock returns to the variance of news about future dividends, and almost $75 \%$ to the variance of news about future excess returns. The decompositions for subsamples are fairly similar; the variance of news about future dividends is never more than $25 \%$ of the variance of excess returns, while the variance of news about future excess returns is never less than $60 \%$ of the variance. Simple regressions of unexpected excess stock returns on the estimated components show a similar pattern. In the full sample, news about future excess returns can explain (in the sense of least-squares regression) more than $85 \%$ of the variance of unexpected excess stock returns, while news about future dividends explains less than $15 \%$ of the variance. Across subsamples, news about excess returns never explains less than $79 \%$ and news about dividends never explains more than $42 \%$ of the variance.

At a mechanical level, the reason why excess return news plays such an important role is that changes in expected excess returns are highly persistent. Thus modest movements in short-run expected returns are capitalized into large changes in stock prices. The persistence of expected returns arises from the persistence of the dividendprice ratio, which is an important forecasting variable for excess stock returns. This point is discussed in greater detail in Campbell (1990a, 1991).

News about real interest rates plays a relatively minor role in the variance decomposition for stock returns. This is particularly true in the earlier subsamples, 1952-79 and 1952-72. In these sample periods the ex post real interest rate is hard to forecast. The $R^{2}$ for the VAR's real interest rate equation (not reported in the table) is only $5 \%$ in $1952-79$, and $6 \%$ in 1952-72. ${ }^{19}$ This lack of forecastability means that the variances and covariances involving real interest rate ncws are tiny and precisely estimated, while the $R^{2}$ statistics for simple regressions of stock returns on real interest rate news are $1 \%$ in the period $1952-79$ and $3 \%$ in $1952-72$.

In the late 1970's and 1980's the real interest rate becomes more forecastable, with

\footnotetext{
10 To some extent of course the relatively high $R^{2}$ statisticn in subsamples rebled overfitting in ornalier data sets.

${ }^{19}$ Even in these sample periods the forecasting variables are jointily significant for the rea interest rate at the $5 \%$ level, indicating that the ex ante real interest rate is not literally constant. This contrasts with Fams's (1975) finding. The restilts here are based on a large information set and use a different price index, which may account for the diffaence in results.
} 
$R^{2}$ statistics (not reported in the table) of $20 \%$ in $1952-87$ and $46 \%$ in $1973-87$. Even here, however, real interest rate variation is largely transitory; it does not cumulate over time in the way that clanges in expected excess returns do. Thus the variance of real interest rate news remains sinall in all our sample periods. There is however an inprecisely estimated positive covariance between real interest rate news and excess return news in the later subsamples. This covariance is attributed to the independent variable in a simple regression of unexpected stock returns on real interest rate news, so the simple regression $R^{2}$ is over $20 \%$ in our sample periods that include the 1980 's.

Table 4 presents a VAR analysis of excess bond returns. The results have some similarities with the results for stock returns, but also some interesting differences. The monthly forecastability of excess bond returns is similar to the forecastability of stock returns over the full sample, with an $R^{2}$ of $5 \%$ and a joint significance level of $0.2 \%$. However the forecastability of bond returns comes from the post-1973 or post-1979 data rather than the earlier data. This is the opposite pattern from Table 3, which showed that stock returns are more forecastable in the earlier subsamples.

In the subperiods 1952-79 and 1952-72, the variance decomposition for bond returns can be described very simply. Almost all the variation in bond returns over this period can be accounted for by news about future inflation, while the other components are small and imprecisely estimated. The variance of inflation news is insignificantly different from the variance of unexpected excess bond returns, and a simple regression of bond returns on inflation news yields an $R^{2}$ insignificantly different from one.

In the sample periods that include 1980's data, the story is somewhat more complicated. Inflation news is still the dominant component of bond returns, whether one looks at variance shares or $R^{2}$ statistics from simple regressions. But now there is some variation in news about future excess returns on bonds, and it appears to be negatively correlated with news about future inflation. In words, this means that when investors learn that long-run inflation will be higher than they expected, they also tend to learn that excess bond returns will be lower than they expected. This has the effect of decreasing bond price variability because the capital loss from higher expected inflation is partly offsct by a capital gain from lower expected excess bond returns. It should be kept in mind, however, that the terms involving excess bond returns in Table 4 are extremely imprecisely estimated. 


\subsection{A Covariance Decomposition for Excess Bond and Stock Returns}

In Tables 5 and 6 we study the determinants of the covariance between excess stock and bond returns. Table 5 reports the correlation matrix of the return components $\epsilon_{d}, \epsilon_{r}, \epsilon_{e}, \xi_{\pi}, \xi_{r}$, and $\xi_{\boldsymbol{z}}$, estimated from a 1-lag VAR over the full sample and each of our subsamples. The first row of Table 6 gives the covariance between the stock return innovation $v_{e}$ and the bond return innovation $v_{x}$. This is always close to zero, as one would expect from the covariances of the raw excess returns reported in Table 2. The lower panels of Table 6 show the covariance of $v_{e}$ with each of the components of $v_{x}$, and the covariance of $v_{x}$ with each of the components of $v_{e}$. Thus Table 6 answers the question, "What would be the covariance of bond and stock returns if one of these asset returns consisted of a single component while the other return were as measured in the data?".

We can now see some of the reasons why the covariance of excess stock and bond returns is so small. In our earlier subsanples 1952-72 and 1952-79, the excess stock return has small covariances with all the components of the excess bond return. In this period stocks do not seem to be negatively affected by long-run increases in inflation, while expected real interest rates and excess bond returns are not very variable.

When we include data from the 1980's, there appear to be offsetting effects. The excess stock return covaries positively with news about future inflation $\xi_{\pi}$, but negatively with news about future real interest rates $\xi_{r}$ and news about future excess bond returns $\xi_{x}$. The negative correlation between the excess stock return and the bond return component $\xi_{x}$ is due largely to a positive correlation between news about future excess stock returns $\epsilon_{e}$ and news about future excess bond returns $\xi_{x}$, shown in Table $5 .{ }^{20}$ In any event, the positive inflation covariance tends to offset the negative real interest rate and excess return covariances, leaving the overall covariance close to zero.

\subsection{Variance Decompositions for Level and Slope Portfolio Returns}

Further insight into these results can be gained from Tables 7 and 8, which decompose the variances of returus on level and slope portiolios. The only two components of returns on the level portfolio of two-month bills are the news about inflation and real interest rates one month ahead. Table 7 shows that these two components have a

\footnotetext{
${ }^{20}$ Fenns and Frend, (1989) emphaxize thin positive correlaxion among expected returns on different long-term anaets. We note howeve that our eatimates of Corr $\left(\varepsilon_{e}, \xi_{+}\right)$never exceed 0.4 .
} 
strong tendency to offset each other. The variances of both news components exceed the variance of the level portfolio return, but they have a large negative covariance. This reflects the fact that short-run forecasts of inflation and real interest rates are negatively correlated. A positive innovation in expected inflation tends to be associated with a negative inmovation in the expected real interest rate, so that the effect on the short-terin nominal interest rate is dampened.

Table 7 also illustrates the point, discussed as a theoretical possibility in section (3.1), that a variable component of an asset return can have almost no explanatory power in a simple regression of the return on that component. According to Table 7 short-term real interest rate variation is important and tends to offset short-term variation in inflation, but because inflation news dominates the level portfolio return the explanatory power of real interest rate news in a simple regression is negligible. ${ }^{21}$

The pattern of results in Table 7 is very striking, but for two reasons it should be interpreted with some caution. First, in the earlier subsamples 1952-79 and 1952-72 the real interest rate terms are not significantly different from zero and the variance share of inflation news is not significantly different from one. This reflects the weak forecastability of ex post real interest rates in this period. Second, forecastable measurement error in inflation might create the pattern of results in Table 7 even in a world in which true real interest rates were constant. Measurement error is unlikely to be the whole explanation, however, as numerous authors have recorded the opposing low-frequency movements of inflation and real interest rates in the late 1970's and early 1980's.

Table 8 gives a variance decomposition for the excess return on a slope portfolio, long 10-year bonds and short 2-month bills. Here again we find an important role for forecasts of both inflation and real interest rates, now measured as changes from a onemonth horizon to a ten-year horizon. Just as in Table 7 , innovations in these forecasts of inflation and real interest rates have a tendency to offset each other. Each considered in isolation implies a more variable portfolio return than we observe, but they have a strong negative covariance which tends to reduce the variability of the slope portfolio return.

It may seem puzzling that real interest rate variation plays an important role for level and slope portfolio returns but is much less important for the excess bond return, winch is the sum of the level and slope portfolios. The reason is that VAR forecasts

\footnotetext{
21 A similar but slightly less drannatic patlem is found in Table 4 for news about excess bond returm.
} 
of the real interest rate have the mean-reverting property that short-run yeal interest rate forecasts are more variable than long-run forecasts. An increase in the expected slort-run real interest rate 1 month aliead is associated with expected decreases in real interest rates between 1 month ahead and 10 years ahead as the expected real interest. rate returns to its long-run average level. Thus the real interest rate components of the level and slope portfolios are negatively correlated and more variable than their sum, which is the real interest rate component of the excess bond return. This fact is documented in Table 9, which gives the correlation matrix of components of the level and slope portfolios. In every sample period the correlation between $\lambda_{r}$ and $\mu_{r}$, the real rate components of the level and slope portfolios, lies between -0.998 and -1.000 .

Tables 7, 8, and 9 also clarify the role of changing expected excess bond returns, or term premiums, in the term structure of interest rates. Recall that Table 4 showed a negative correlation between long-run expected inflation and term premiums, helping to dampen the variability of cxcess bond returns. Table 9 , by contrast, reports a positive correlation between the inflation component of the slope portfolio, $\mu_{\pi}$, and the term premium component, $\boldsymbol{\mu}_{\boldsymbol{x}}$. Table $\delta$ shows that this increases the variance of the slope portfolio return, which is the conditional variance of the yield spread.

The results in Tables 8 and 9 are consistent with the result in Table 4 because VAR forecasts of inflation rates also display some mean-reversion, albeit less strong than in the case of real interest rates. Table 9 shows that the inflation components of the level and slope portfolios, $\lambda_{\pi}$ and $\mu_{\pi}$, are highly negatively correlated. A $1 \%$ increase in expected inflation over a 10 -year horizon is typically associated with a greater than $1 \%$ increase in expected inflation 1 month ahead, so that cxpected inflation rates fall between the 1 month and 10 year lorizons. This by itself lowers the yield spread; at the same time the term premium falls, amplifying the decline in the spread. 


\section{Conclusions}

In this paper we have used a dynamic accounting framework and time-series econometric methods to break excess returns on long-term assets into components associated with news about future cash flows and discount rates. Since we use an accounting framework rather than a behavioral model, we are able to make statements only about proximate causes and not about fundamental causes of asset price movements. Nevertheless, our empirical results shed light on several issues that have been debated in the finance literature during the last ten years.

Our first important finding is that a large part of the variance of excess stock returns is attributable to changing expectations of future excess stock returns. The postwar U.S. stock market displays "excess volatility" in the sense that returns have a standard deviation two or three times greater than the standard deviation of news about future dividend growth. We obtain this result by calculating the implications of a return forecasting equation, making no assumptions about the dividend process; news about dividends is treated as a residual component of the stock return. At a mechanical level, the result comes from the fact that our forecasts of excess stock returns are highly persistent, so that small changes in forecast monthly returns cumulate over time and have a big effect on the stock price. ${ }^{22}$

An important unanswered question is what economic forces create these persistent changes in expected excess stock returns. Our second finding is that these changes are not associated with important changes in long-horizon forecasts of real interest rates. The real interest rate component of the excess stock return has a much smaller variance than the other components. This suggests that theoretical models of stock market pricing should not rely heavily on changing real interest rates. Homoskedastic exchange models like that of Cecchetti, Lam, and Mark (1990) tend to generate large variations in real interest rates and small variations in equity risk premiums; the opposite patiern is needed to fit the data.

A similar point can be made for bond returns. The theoretical finance literature contains numerous pricing models for real bonds, and these are sometimes applied to data on the nominal term structure (Gibbons 1989, Gibbons and Ramaswamy 1986). But we find that the variance of excess returns on long-term nominal bonds is accounted

\footnotetext{
22 This is related to the fact that long-horizon excess stock relurns are more highly forecatable than short-horizon excess relurms (Fama and Frendi 1988a,b). Campbell (1991) and Kandel and Slambaugh (1988) explore the implications of a VAR forecasting system for long-horizon forecustability of retums.
} 
for primarily by news about future inflation rates, which would have no impact if bonds had real payoffs. Real bond pricing models cannot be applied to the nominal term structure unless the price of inflation risk is exactly zero; if the inflation risk price is even slightly positive or negative, the inflation risk premium will be large and will tend to dominate the pricing of nominal bonds. ${ }^{23}$

Although long-horizon forccasts of real interest rates arc not highly variable, there are short-run changes in the ex ante real interest rate. We find that news about the real interest rate one month aliead is an important component of the variance of the excess return on 2-month bills over 1-month bills (the "level portfolio" return). Therc is a strong negative covariance between one-montli-ahead forecasts of inflation and real interest rates, so that the short-term nominal interest rate would be considerably more variable if the ex ante real interest rate were constant. ${ }^{24}$ Since the real interest rate does help to move the short-term interest rate, but has little inpact on the long-term bond yield, we find that real interest rate news is also a major factor accounting for the variability of the yield spread between 10-year bonds and 1-month bills (equivalently, the variability of a "slope portfolio" return long 10-year bonds and short 2-montl bills). These results are consistent with the findings of Fama (1990) and Mishkin (1990).

In the later part of our sample period, there is evidence that cxcess bond returns are predictable. But news about future excess returns contributes less to volatility in the bond market than in the stock market. The reason for this scems to be that our forecasts of excess bond returns are less persistent than our forecasts of excess stock returns.

Wc also find some evidence that during the 1980 's, news about excess bond returns is negatively correlated with news about future inflation over the life of a 10-year bond. This reduces bond price variability because capital losses from higher expected inflation are partially offset by capital gains from lower expected excess bond returns. Tlue correlation between excess bond returns and inflation has a different effect on the yicld spread, however. News that inflation is higher tends to increase short-term expected inflation and the short-term nominal interest rate more than long-term expected inflation and the long-term nominal interest rate; thus positive inflation news tends to be associated with a decline in the yicld spread. The negative corrclation between

\footnotetext{
${ }^{23}$ Of course, real bond pricing modelo can sometimes be reinterpreted as nominal bond pricing models by changing to a nominal numeraire. However this may affect the plausibility of the underlying equilibrium specification.

24 This makes it unlikely that the inflation risk prenium is zero, since inflation surprisa are correlaced with short-term changes in the investment opportunity set. Canplell (1990b) discusse cross-sections asset pricing in the context of a VAR model like the one used here.
} 
term premiums and inflation accentuates this decline, so the variability of the yield spread is increased. Long-term bond yields "underreact" to inflation and yield spreads "overreact", as described by Campbell and Sliller $(1984,1991)$.

Finally, our results help to explain why bond and stock returns are practically uncorrelated in postwar mouthly U.S. data. There are several reasons for this. First, the only component which is common to both assets is the news about real interest rates, but this component has relatively little variability. Second, there is positive correlation between news about future excess returns on bonds and stocks, as clained by Fama and French (1989); but the correlation never exceeds 0.4 and this is not sufficient to produce a large positive covariance between the two asset returns given the relatively small variability of news about future excess bond returns. Third, there is a weak positive correlation between the stock return and news about long-term future inflation (the major component of the bond return). This tends to make bond and stock returns covary negatively, offsetting the positive covariance coming from the real interest rate and expected excess return effects.

Barsky (1989) has suggested that the weak correlation of bond and stock returns could be due to a tendency for equity risk premiums to increase when the short-term real interest rate falls. If term premiums are close to constant, declining real intercst rates would be associated with a rising bond market but a flat or even declining stock market. Our empirical results do not support this explanation. We do not find that real interest rate changes are important in moving either bond or stock prices. Also, in the later part of our sample period we find a significantly positive correlation between news about real interest rates and news about equity premiums; in the earlier part of the period the correlation is negative but small and insignificant.

The major caveat about all the results presented here is that they are dependent on a particular specification of the information set available to investors. The results do not seem to be very sensitive to the number of lags we include in our VAR system, but it is always possible that there are omitted forecasting variables that could change the decompositions of excess returns.

The variance decompositions reported here should have several interesting applications in cross-sectional asset pricing. First, the metlods of this paper can be applied to international stock market data to try to account for the common variation in different national stock price indexes. Sccond, the methods of this paper can be used to 
study the cross-sectional behavior of assets' betas with the aggregate stock market. Bctas, like variances and covariances, can be broken into components due to news about cash flows and news about future discount rates. Finally, the importance of changing expected excess stock returns suggests that the intertemporal asset pricing literature, which allows for changes in the investment opportunity set, is empirically relevant for postwar U.S. data. It should be possible to use intertemporal asset pricing theory to restrict the structure of the VAR models used in this paper. ${ }^{25}$

${ }^{25}$ Campbell (19906) is a first step in this direction. 


\section{Appendix A: Stock Return Calculations}

The $\log$ real return on a stock, which we write $h_{t+1}$, is defined by $h_{t+1}=\log \left(P_{t+1}+\right.$ $\left.D_{l+1}\right)-\log \left(P_{l}\right)$, where $P_{l}$ and $D_{l}$ are the levels (not $\operatorname{logs}$ ) of the end-of-period real stock price and dividend respectively. The dividend-ratio model of Campbell and Sliller (1988a) is derived by taking a first-order Taylor approximation of this equation. The resulting approximation is

$$
h_{t+1} \approx k+d_{t}-p_{t}-\rho\left(d_{t+1}-p_{t+1}\right)+\Delta d_{t+1}
$$

where lower-case letters denote logs of the corresponding upper-case letters. The parameter $\rho$ is the average ratio of the stock price to the sum of the stock price and the dividend, and the constant $k$ is a nonlinear function of $\rho{ }^{26}$ Equation (A.1) says that the return on stock is high if the $\log$ dividend-price ratio is high when the stock is purchased, if dividend growth occurs during the holding period, and if the log dividendprice ratio falls during the holding period.

Equation (A.1) can be thought of as a difference equation relating $d_{t}-p_{t}$ to $d_{t+1}-p_{t+1}, \Delta d_{t+1}$ and $h_{t+1}$. Solving forward, and imposing the terminal condition that $\lim _{i \rightarrow \infty} \rho^{i}\left(d_{t+i}-p_{t+i}\right)=0$, Campbell and Shiller (1988a) obtain

$$
d_{\ell}-p_{t}=\sum_{j=0}^{\infty} \rho^{j}\left[h_{\ell+1+j}-\Delta d_{t+1+j}\right]-\frac{k}{1-\rho} .
$$

This equation says that the $\log$ dividend-price ratio $d_{t}-p_{t}$ can be written as a discounted value of all future returns $h_{t+1+j}$ and dividend growth rates $\Delta d_{t+1+j}$, discounted at the constant rate $\rho$ lcss a constant $k /(1-\rho)$. If the dividend-price ratio is high today, this will give high future returns unless dividend growth is low in the future. It is important to note that all the variables in (A.2) are measured ex post; (A.2) has been obtained only by the linear approximation of $h_{t+1}$ and the imposition of a condition that $\delta_{t+i}$ does not explode as $i$ increases.

\footnotetext{
${ }^{26}$ Equation (A.1) and the other formulas given here differ alightly from those in Campbell and Shiller (1988a, 1988b) because the notation here uses a different timing convention. In this paper, as in Campbell (1990, 1991), we define the time $t$ stock price and conditional expectation of future variables to be measured at the end of period $t$ rather than the teginning of period $l$. This conforms with the more standard practice in the finance literature.
} 
However (A.2) also holds ex ante. If one takes expectations of equation (A.2), conditional on information available at the end of time period $t$, the left land side is unchanged since $d_{t}-p_{t}$ is in the information set, and the right hand side becomes an expected discounted value. Using the ex ante version of (A.2) to substitute $d_{t}-P$ and $d_{t+1}-p_{t+1}$ out of $(\mathrm{A} .1)$, we obtain

$$
\begin{aligned}
h_{t+1}-E_{t} h_{t+1} & =\left(E_{t+1}-E_{t}\right) \sum_{j=1}^{\infty} \rho^{j-1} \Delta d_{t+j} \\
& -\left(E_{t+1}-E_{t}\right) \sum_{j=1}^{\infty} \rho^{j} h_{t+1+j}
\end{aligned}
$$

To obtain the equations in the text, we use the definition of the excess return,

$$
e_{t+1} \equiv h_{t+1}-r_{t+1}
$$

To obtain (2.1) we substitute (A.4) into (A.3). To obtain (2.6) we substitute (A.4) into (A.2). (2.5) then follows straightforwardly from (2.6).

In the empirical work in the paper, we use sample means to set $\rho=0.9962$. The results are not sensitive to variation in $\rho$ within a plausible range. Campbell and Shiller (1988a) conduct an extensive analysis of the accuracy of the approximation described in this Appendix. 


\section{Appendix B: Bond Return Calculations}

Define the log nominal price of an $n$-period nominal bond at time $t$ as $p_{n, t}$. Define the $\log$ nominal 1-period holding return on a bond with $n$ periods to maturity at tine $t$, held from $t$ to $t+1$, as

$$
b_{n, t+1} \equiv p_{n-1, t+1}-p_{n, t}
$$

Equation (B.1) can be thought of as a difference equation in the log bond price. It can be solved forward to the maturity date of the bond, using the fact that at this date the bond price is unity so its log price is zero: $p_{0, t+n}=0$. We obtain

$$
\begin{aligned}
p_{n, t} & =-\left[b_{n, t+1}+b_{n-1, t+2}+\ldots+b_{1, t+n}\right] \\
& =-\sum_{i=0}^{n-1} b_{n-i, t+1+i} .
\end{aligned}
$$

Equation (B.2) holds ex post, but it also holds ex ante. If one takes expectations of equation (B.2) at date $t$, the left hand side remains unchanged because the nominal bond price is in the information set at time $t$. The right hand side becomes a sum of expected future returns, rather than realized returns:

$$
p_{n, t}=-E_{t} \sum_{i=0}^{n-1} b_{n-i, t+1+i}
$$

Equation (B.3) can be substituted into (B.1) to express the log nominal bond return as a function of news about future nominal bond returns:

$$
b_{n, t+1}-E_{t} b_{n, t+1}=-\left(E_{t+1}-E_{t}\right) \sum_{i=1}^{n-1} b_{n-i, t+1+i} .
$$


This equation expresses the well-known fact that nominal bond returns are known orer the life of the bond, so that unexpected positive nominal returns today are always offset by decreases in expected future nominal returns.

For our purposes, it will be more useful to work with excess bond returns. We define the log excess 1-period bond return as

$$
x_{n, t+1} \equiv b_{n, t+1}-\pi_{t+1}-r_{t+1}
$$

To obtain (2.3) we substitute (B.5) into (B.4). To obtain (2.7) we substitute (B.5) into (B.3) and then use the fact that $y_{n, t}=-p_{n, t} / n$. Equation (2.8) follows straightforwardly. 


\section{Appendix C: VAR Calculations}

Given the state vector and VAR system defined in section 3, the components of asset returns can be derived as follows. For stock returns, we have

$$
\begin{aligned}
& \epsilon_{e, t+1}=e 1^{\prime} \sum_{j=1}^{\infty} \rho^{j} A^{j} w_{t+1}=e 1^{\prime} \rho A(I-\rho A)^{-1} w_{l+1} \\
& \epsilon_{r, l+1}=e 2^{\prime} \sum_{j=0}^{\infty} \rho^{j} A^{j} w_{l+1}=e 2^{\prime}(I-\rho A)^{-1} w_{\ell+1} \\
& \epsilon_{d, l+1}=v_{e, l+1}+\epsilon_{e, l+1}+\epsilon_{r, l+1} .
\end{aligned}
$$

The components of the excess bond return can be obtained in a similar manner. We have

$$
\begin{aligned}
& \xi_{r, t+1}=e 2^{\prime} \sum_{j=1}^{n-1} A^{j} w_{t+1}=e 2^{\prime}(I-A)^{-1}\left(A-A^{n}\right) w_{t+1} \\
& \xi_{\pi, t+1}=-\xi_{r, t+1}+e 3^{\prime}\left\{(I-A)^{-1}\left[(n-1) I+(I-A)^{-1}\left(A^{n}-A\right)\right]\right\} w_{l+1} \\
& \xi_{x, t+1}=-v_{x, t+1}-\xi_{r, t+1}-\xi_{\pi, t+1} .
\end{aligned}
$$

For the level portfolio, we have

$$
\begin{aligned}
& \lambda_{r, l+1}=(n-1) e 2^{\prime} A w_{t+1} \\
& \lambda_{\pi, t+1}=-v_{l, l+1}-\lambda_{r, t+1} .
\end{aligned}
$$

For the slope portfolio, we define a matrix $C_{n}=(1 / n)(I-A)^{-1}\left(I-A^{n}\right)-I$. Then 


$$
\begin{aligned}
& \mu_{r, \ell+1}=(n-1) e 2^{\prime} A C_{n-1} u^{\prime} t+1 \\
& \mu_{\pi, l+1}=-\mu_{r, l+1}-(n-1) \epsilon 3^{\prime}(I-A)^{-1} A C_{n-1} u_{t+1} \\
& \mu_{x, l+1}=\xi_{x, l+1}=-v_{m, t+1}-\mu_{r, t+1}-\mu_{\pi, t+1} .
\end{aligned}
$$




\section{Bibliography}

Barsky, Robert B., 1989, "Why Don't the Prices of Stocks and Bonds Move Together?", American Economic Review 79:1132-1145.

Barsky, Robert B. and J. Bradford DeLong, 1989, "Why Have Stock Prices Fluctuated?", unpublished paper.

Campbell, John Y., 1987, "Stock Returns and the Term Structure", Journal of Financial Economics 18:373-399.

Campbell, John Y., 1990a, "Measuring the Persistence of Expected Returns", American Economic Review Papers and Proceedings 80:43-47.

Campbell, John Y., 1990b, "Intertemporal Asset Pricing without Consumption", Financial Research Center Memorandum No. 119, Princeton University.

Campbell, John Y., 1991, "A Variance Decomposition for Stock Returns", the H.G. Johnson Lecture to the Royal Economic Society, Economic Journal 101, 157-179.

Campbell, John Y. and Robert J. Shiller, 1984, "A Simple Account of the Behavior of Long-Term Interest Rates", with Robert J. Shiller, American Economic Revicw Papers and Proceedings 74:44-48.

Campbell, John Y. and Robert J. Shiller, 1987, "Cointegration and Tests of Present Value Models", Journal of Political Economy 95:1062-1088.

Campbell, John Y. and Robert J. Shiller, 1988a, "The Dividend-Price Ratio and Expectations of Future Dividends and Discount Factors", Review of Financial Studies 1:195-228.

Campbell, John Y. and Robert J. Shiller, 1988b, "Stock Prices, Earnings, and Expected Dividends", Journal of Finance 43:661-676.

Campbell, John Y. and Robert J. Shiller, 1991, "Yield Spreads and Interest Rate Movements: A Bird's Eye View", forthcoming Review of Economic Studies.

Cecchetti, Stephen G., Pok-sang Lam, and Nelson C. Mark, 1990, "Mean Reversion in Equilibrium Asset Prices", American Economic Review 80:398-418.

Conrad, Jennifer and Gautam Kaul, 1988, "Time-Variation in Expected Returns", Joutral of Business 61:409-425.

Cutler, David M., James M. Poterba, and Lawrence H. Summers, 1989, "What Moves Stock Prices?", Journal of Portfolio Management 15:4-12.

Cutler, David M., James M. Poterba, and Lawrence H. Summers, 1990, "Speculative Dynamics", NBER Working Paper No. 3242.

Estrella, Arturo and Gikas A. Hardouvelis, 1991, "The Term Structure as a Predictor of Real Economic Activity", Journal of Finance 46:555-576.

Fama, Eugene F., 1075, "Short Term Interest Rates as Predictors of Infiation", Amcrican Economic Review 65:269-282. 
Fama, Eugenc F., 1984, "The Information in the Term Structure", Journal of Financial Economics 13:509-528.

Fana, Eugene F., 1990a, "Stock Returns, Expected Returns, and Real Activity", Journal of Finance 45:1089-1108.

Fana, Eugene F., 1990b, "Term-Structure Forecasts of Interest Rates, Inflation, and Real Returns", Journal of Monetary Economics 25:59-76.

Fama, Eugene F. and Robert R. Bliss, 1987, "The Information in Long-Maturity Forward Rates", American Economic Review 77:680-692.

Fama, Eugene F. and Kenneth R. French, 1988a, "Permanent and Temporary Components of Stock Prices", Journal of Political Economy 96:246-273.

Fama, Eugene F. and Kenneth R. French, 1988b, "Dividend Yields and Expected Stock Returns", Journal of Financial Economics 22:3-25.

Fama, Eugene F. and Kenneth R. French, 1989, "Business Conditions and Expected Returns on Stocks and Bonds", Journal of Financial Economics 25:23-49.

Fama, Eugene F. and G. William Schwert, 1977, "Asset Returns and Inflation", Journal of Financial Economics 5:115-146.

Gibbons, Michael R., 1989, "On the Volatility of Bond Prices", Carnegie-Rochester Conference Scries on Public Policy 31:139-176.

Gibbons, Michael R. and Krishna Ramaswamy, 1986, "The Term Structure of Interest Rates: Empirical Evidence", unpublished paper, Wharton School, University of Pennsylvania.

Hansen, Lars Peter, 1982, "Large Sample Properties of Gencralized Method of Moments Estimators", Econometrica 50:1029-1054.

Hodrick, Robert J., 1991, "Dividend Yields and Expected Stock Returns: Alternative Procedures for Inference and Measurement", Working Paper No. 88, Departinent of Finance, Kellogg School, North western University.

Kandel, Shmuel and Robert F. Stambaugh, 1988, "Modelling Expected Stock Returns for Short and Long Horizons", Working Paper 42-88, Roducy L. White Center for Financial Research, Wharton School, University of Pennsylvania.

Keim, Donald B. and Robert F. Stambaugh, 1986, "Predicting Returns in the Stock and Bond Markets", Journal of Financial Economics 17:357-390.

Kleidon, Allan W., 1986, "Variance Bounds Tests and Stock Price Valuation Models", Journal of Political Economy 94:953-1001.

Lchmann, Bruce N., 1991, "Earnings, Dividend Policy, and Present Value Relations: Building Blocks of Dividend Policy Invariant Cash Flows", NBER Working Paper No. 3676 .

Litterman, Robert B. and Laurence Weiss, 1985, "Money, Real Interest Rates and Output: A Reinterpretation of Postwar U.S. Data", Econometrica 53:129-156.

Lo, Andrew W. and A. Craig MacKinlay, 1988, "Stock Market Prices Do Not Follow 
Random Walks: Evidence from a Simple Specification Test", Review of Financial Studies 1:41-66.

McCulloch, J. Huston, 1990, "U.S. Government Term Structure Data", appendix to Robert J. Shiller "The Term Structure of Interest Rates", in Benjamin Friednan and Frank Hahn eds. The Handbook of Monetary Economics, Amsterdam: NorthHolland.

Misllkin, Frederic S., 1990, "What Does the Term Structure Tell Us About Future Inflation?", Journal of Monetary Economics 25:77-95.

Nelson, Charles R. and Myung J. Kim, 1990, "Predictable Stock Returns: Reality or Statistical Illusion?", NBER Working Paper No. 3297.

Poterba, James M. and Lawrence H. Summers, 1988, "Mean Reversion in Stock Prices: Evidence and Implications", Journal of Financial Economics 22:27-59.

Richardson, Matthew, "Temporary Components of Stock Prices: A Skeptic's View", unpublished paper, Graduate School of Business, Stanford University, 1989.

Richardson, Matthew and James H. Stock, 1989, "Drawing Inferences from Statistics Based on Multi-Year Asset Returns", Journal of Financial Economics 25, 323-348.

Roll, Richard, 1988, " $R$ ", Journal of Finance 43:541-566.

Shiller, Robert J., 1990, "The Term Structure of Interest Rates", in Benjamin Friedman and Frank Hahn eds. The Handbook of Monetary Economics, Amsterdam: NorthHolland.

Shiller, Robert J. and Andrea E. Beltratti, 1990, "Stock Prices and Bond Yields: Can Their Comovements Be Explained in Terms of Present Value Models?", NBER Working Paper No. 3464.

Shiller, Robert J., John Y. Campbell, and Kermit L. Schoenholtz, 1983, "Forward Rates and Future Policy: Interpreting the Term Structure of Interest Rates", Brookings Papers on Economic Activity 1:173-217.

Stambaugh, Robert F., 1990, "Factors in Expected Returns", unpublished paper, Wharton School, University of Pennsylvania.

Stock, James H. and Mark W. Watson, 1990, "Business Cycle Properties of Selected U.S. Economic Time Series, 1959-1988", NBER Working Paper No. 3376.

White, Halbert, 1984, Asymptotic Theory for Econometricians, Academic Press: Orlando, Florida. 


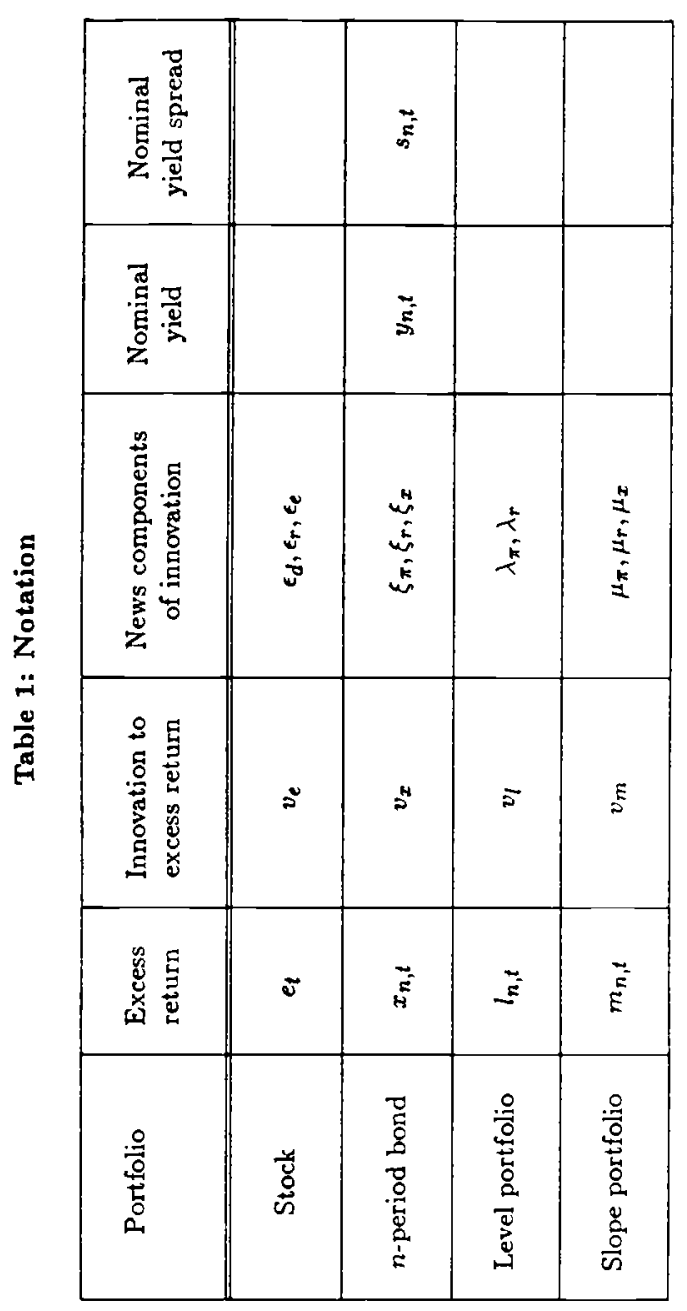

을

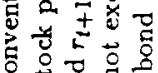

80

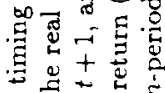

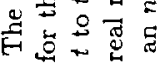

혀응

함

总壳总

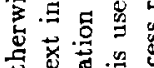

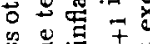

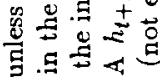

总总总吉

声声品

焉总我我

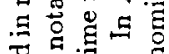

总点它吉

氞吉志至

\& 1 ,

岂诺

要造



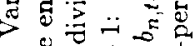

$+0$

응

Eᄃ

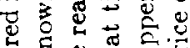

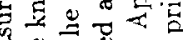

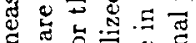

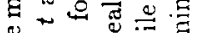

苞导导吉

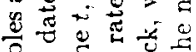

.



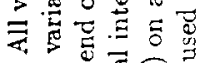

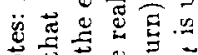

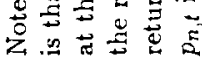


Table 2: Variances, Covariances, and Correlations of Portfolio Returns

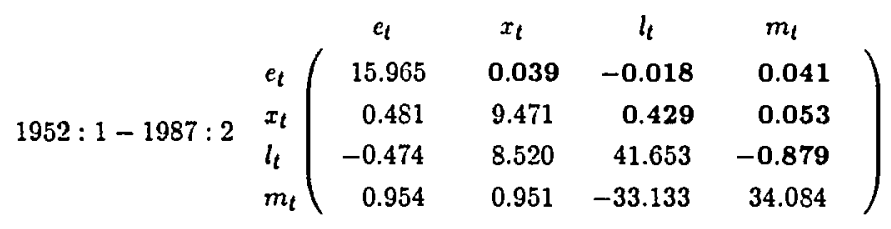

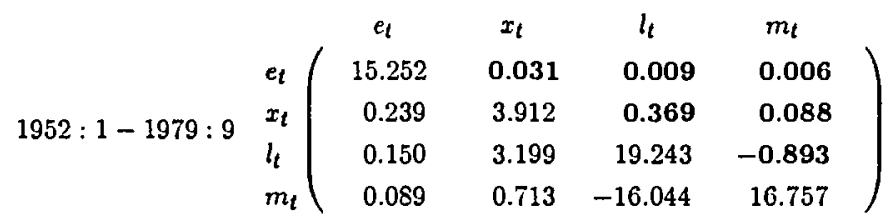

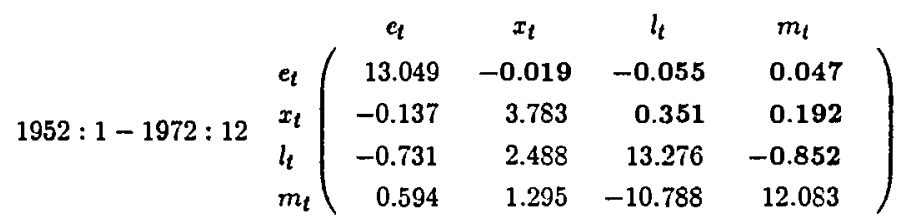

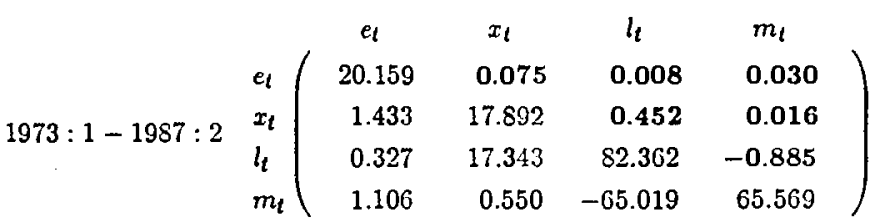

Notes: $c_{t}, x_{t}, l_{t}$ and $m_{t}$ are the excess returns on stocks, 10-year zero-coupon bonds, a level portfolio of 2-month bills, and a slope portfolio long 10-year bonds and short 2-month bills. All excess returns are measured in percentage points, monthly, relative to the return on a 1-month bill. Sample variances and covariances are shown along and below the diagonal of each matrix; correlations are shown in bold face above the diagonal. 
Table 3: Variance Decomposition for Excess Stock Returns

\begin{tabular}{|c|c|c|c|c|c|}
\hline $\begin{array}{l}\text { VAR lag lengtl } \\
\text { Sample period }\end{array}$ & $\begin{array}{c}1 \\
52: 1-87: 2\end{array}$ & $\begin{array}{c}1 \\
52: 1-79: 9\end{array}$ & $\frac{1}{52: 1-72: 12}$ & $\begin{array}{c}1 \\
73: 1-87: 2\end{array}$ & $\begin{array}{c}3 \\
52: 1-87: 2\end{array}$ \\
\hline $\begin{array}{l}\text { Return } R^{2} \\
\text { Significance }\end{array}$ & $\begin{array}{l}0.054 \\
0.001\end{array}$ & $\begin{array}{l}0.096 \\
0.000\end{array}$ & $\begin{array}{l}0.126 \\
0.000\end{array}$ & $\begin{array}{l}0.065 \\
0.106\end{array}$ & $\begin{array}{l}0.082 \\
0.015\end{array}$ \\
\hline \multicolumn{6}{|l|}{ Shares of: } \\
\hline $\operatorname{Var}\left(\epsilon_{d}\right)$ & $\begin{array}{c}0.138 \\
(0.022)\end{array}$ & $\begin{array}{c}0.180 \\
(0.062)\end{array}$ & $\begin{array}{c}0.237 \\
(0.112)\end{array}$ & $\begin{array}{c}0.141 \\
(0.070)\end{array}$ & $\begin{array}{c}0.095 \\
(0.021)\end{array}$ \\
\hline$-2 \operatorname{Cov}\left(\epsilon_{d}, \epsilon_{r}\right)$ & $\begin{array}{c}-0.016 \\
(0.020)\end{array}$ & $\begin{array}{c}-0.017 \\
(0.014)\end{array}$ & $\begin{array}{c}-0.024 \\
(0.027)\end{array}$ & $\begin{array}{c}-0.091 \\
(0.078)\end{array}$ & $\begin{array}{r}-0.013 \\
(0.018)\end{array}$ \\
\hline$-2 \operatorname{Cov}\left(\epsilon_{d}, \epsilon_{e}\right)$ & $\begin{array}{c}0.008 \\
(0.178)\end{array}$ & $\begin{array}{c}0.104 \\
(0.189)\end{array}$ & $\begin{array}{c}0.179 \\
(0.125)\end{array}$ & $\begin{array}{r}-0.409 \\
(0.349)\end{array}$ & $\begin{array}{c}0.050 \\
(0.120)\end{array}$ \\
\hline $\operatorname{Var}\left(c_{r}\right)$ & $\begin{array}{c}0.016 \\
(0.006)\end{array}$ & $\begin{array}{c}0.006 \\
(0.002)\end{array}$ & $\begin{array}{c}0.005 \\
(0.003)\end{array}$ & $\begin{array}{c}0.044 \\
(0.028)\end{array}$ & $\begin{array}{c}0.023 \\
(0.009)\end{array}$ \\
\hline $2 \operatorname{Cov}\left(\epsilon_{r}, \epsilon_{e}\right)$ & $\begin{array}{c}0.112 \\
(0.061)\end{array}$ & $\begin{array}{c}-0.012 \\
(0.048)\end{array}$ & $\begin{array}{r}-0.012 \\
(0.041)\end{array}$ & $\begin{array}{c}0.283 \\
(0.159)\end{array}$ & $\begin{array}{c}0.103 \\
(0.064)\end{array}$ \\
\hline $\operatorname{Var}\left(\epsilon_{e}\right)$ & $\begin{array}{c}0.742 \\
(0.181)\end{array}$ & $\begin{array}{c}0.738 \\
(0.235)\end{array}$ & $\begin{array}{c}0.615 \\
(0.205)\end{array}$ & $\begin{array}{c}1.033 \\
(0.237)\end{array}$ & $\begin{array}{c}0.742 \\
(0.133)\end{array}$ \\
\hline$R^{2}\left(\epsilon_{d}\right)$ & $\begin{array}{c}0.130 \\
(0.202)\end{array}$ & $\begin{array}{c}0.279 \\
(0.285)\end{array}$ & $\begin{array}{c}0.417 \\
(0.219)\end{array}$ & $\begin{array}{c}0.085 \\
(0.170)\end{array}$ & $\begin{array}{c}0.136 \\
(0.168)\end{array}$ \\
\hline$R^{2}\left(\epsilon_{r}\right)$ & $\begin{array}{c}0.257 \\
(0.183)\end{array}$ & $\begin{array}{c}0.012 \\
(0.081)\end{array}$ & $\begin{array}{c}0.029 \\
(0.113)\end{array}$ & $\begin{array}{c}0.446 \\
(0.238)\end{array}$ & $\begin{array}{c}0.202 \\
(0.174)\end{array}$ \\
\hline$R^{2}\left(c_{e}\right)$ & $\begin{array}{c}0.867 \\
(0.017)\end{array}$ & $\begin{array}{c}0.834 \\
(0.039)\end{array}$ & $\begin{array}{c}0.793 \\
(0.077)\end{array}$ & $\begin{array}{c}0.910 \\
(0.011)\end{array}$ & $\begin{array}{c}0.903 \\
(0.020)\end{array}$ \\
\hline
\end{tabular}

Notes: This table is based on a monthly VAR that iucludes the cxcess stock return, real interest rate, change: in tic 1-month bill rate, 10-year and 2-month yicld spreads, $\log$ dividend-price ratio, and relative bill rate? (the difference between the bill rate and a 1 -year backwards moving average). "Return $R^{2}$ " is the $R^{2}$ in thic regression of the excess stock return on the VAR explanatory variables, while "Significance" is the joint significance of the explanatory variables in this regression. The VAR is used to calculate the corriponents of the unexpected excess stock return $v_{e, t+1}$ in equation $(2.2), v_{e, t+1}=\epsilon_{d, t+1}-\epsilon_{r, 1+1}-\epsilon_{e, 1+1}$. The component $\epsilon_{d, t+1}$ can be interpreted as news about future dividends, while $\epsilon_{r_{2} l+1}$ is news about fulure rcal interest ratcs and $c_{t, t+1}$ is new's abollt future excess stock returns. The table reports the variances and covariances of these components, divided by the variance of $v_{e, t+1}$ so that the numbers reported add up to one. The bottom partcl gives the implied $R^{2}$ statistics from simple regressions of $v_{e, 1+1}$ on each component. Asymptotic standard errors are reported in parentheses below each statistic in the table. 
Table 4: Variance Decomposition for Excess Bond Returus

\begin{tabular}{|c|c|c|c|c|c|}
\hline $\begin{array}{l}\text { VAR lag lengtli } \\
\text { Sample period }\end{array}$ & $\begin{array}{c}1 \\
52: 1-87: 2\end{array}$ & $\frac{1}{52: 1-79: 9}$ & $\begin{array}{c}1 \\
52: 1-72: 12\end{array}$ & $\begin{array}{c}1 \\
73: 1-87: 2\end{array}$ & $\begin{array}{c}3 \\
52: 1-87: 2\end{array}$ \\
\hline $\begin{array}{l}\text { Return } R^{2} \\
\text { Significallce }\end{array}$ & $\begin{array}{l}0.051 \\
0.002\end{array}$ & $\begin{array}{l}0.025 \\
0.276\end{array}$ & $\begin{array}{l}0.029 \\
0.383\end{array}$ & $\begin{array}{l}0.073 \\
0.062\end{array}$ & $\begin{array}{l}0.092 \\
0.003\end{array}$ \\
\hline Sliares of: & & & & & \\
\hline $\operatorname{Var}\left(\xi_{x}\right)$ & $\begin{array}{c}1.904 \\
(0.885)\end{array}$ & $\begin{array}{c}1.280 \\
(0.402)\end{array}$ & $\begin{array}{c}0.951 \\
(0.384)\end{array}$ & $\begin{array}{c}2.288 \\
(1.492)\end{array}$ & $\begin{array}{c}2.383 \\
(1.314)\end{array}$ \\
\hline $2 \operatorname{Cov}\left(\xi_{x}, \xi_{r}\right)$ & $\begin{array}{c}-0.209 \\
(0.147)\end{array}$ & $\begin{array}{c}-0.011 \\
(0.061)\end{array}$ & $\begin{array}{c}0.086 \\
(0.079)\end{array}$ & $\begin{array}{c}-0.338 \\
(0.333)\end{array}$ & $\begin{array}{c}-0.287 \\
(0.097)\end{array}$ \\
\hline $2 \operatorname{Cov}\left(\xi_{x}, \xi_{x}\right)$ & $\begin{array}{c}-1.532 \\
(1.482)\end{array}$ & $\begin{array}{c}-0.452 \\
(0.538)\end{array}$ & $\begin{array}{r}-0.167 \\
(0.444)\end{array}$ & $\begin{array}{c}-2.172 \\
(2.613)\end{array}$ & $\begin{array}{l}-2.108 \\
(2.205)\end{array}$ \\
\hline $\operatorname{Var}\left(\xi_{r}\right)$ & $\begin{array}{c}0.029 \\
(0.013)\end{array}$ & $\begin{array}{c}0.021 \\
(0.007)\end{array}$ & $\begin{array}{c}0.018 \\
(0.013)\end{array}$ & $\begin{array}{c}0.054 \\
(0.036)\end{array}$ & $\begin{array}{c}0.042 \\
(0.017)\end{array}$ \\
\hline $2 \operatorname{Cov}\left(\xi_{r}, \xi_{x}\right)$ & $\begin{array}{c}0.051 \\
(0.108)\end{array}$ & $\begin{array}{c}-0.003 \\
(0.038)\end{array}$ & $\begin{array}{c}0.013 \\
(0.047)\end{array}$ & $\begin{array}{c}0.066 \\
(0.253)\end{array}$ & $\begin{array}{c}0.093 \\
(0.164)\end{array}$ \\
\hline $\operatorname{Var}\left(\xi_{x}\right)$ & $\begin{array}{c}0.758 \\
(0.695)\end{array}$ & $\begin{array}{c}0.165 \\
(0.173)\end{array}$ & $\begin{array}{c}0.099 \\
(0.104)\end{array}$ & $\begin{array}{c}1.102 \\
(1.256)\end{array}$ & $\begin{array}{c}0.878 \\
(0.959)\end{array}$ \\
\hline$R^{2}\left(\xi_{x}\right)$ & $\begin{array}{c}0.560 \\
(0.225)\end{array}$ & $\begin{array}{c}0.859 \\
(0.112)\end{array}$ & $\begin{array}{c}0.871 \\
(0.109)\end{array}$ & $\begin{array}{c}0.466 \\
(0.268)\end{array}$ & $\begin{array}{c}0.589 \\
(0.232)\end{array}$ \\
\hline$R^{2}\left(\xi_{r}\right)$ & $\begin{array}{c}0.087 \\
(0.090)\end{array}$ & $\begin{array}{c}0.009 \\
(0.032)\end{array}$ & $\begin{array}{c}0.255 \\
(0.189)\end{array}$ & $\begin{array}{c}0.125 \\
(0.120)\end{array}$ & $\begin{array}{c}0.074 \\
(0.080)\end{array}$ \\
\hline$R^{2}\left(\xi_{x}\right)$ & $\begin{array}{c}0.000 \\
(0.011)\end{array}$ & $\begin{array}{c}0.024 \\
(0.116)\end{array}$ & $\begin{array}{c}0.005 \\
(0.097)\end{array}$ & $\begin{array}{c}0.002 \\
(0.026)\end{array}$ & $\begin{array}{c}0.019 \\
(0.065)\end{array}$ \\
\hline
\end{tabular}

Notes: This table is based on a monthly VAR that includes the excess stock return, rea! interest rate, cliange in the 1-month bill rate, 10-year and 2-month yield spreads, log dividend-price ratio, and relative bill rate (the difference between the bill rate and a l-year backwards moving average). "Return $R^{2 "}$ is the implied $l^{2}$ in a regression of the excess bond return on the VAR explanatory variables, while "Significance" is the joint significance of the explanatory variables in this regression. The VAR is used to calculate the components of the unexpected bond return $v_{x, t+1}$ in equation $(2.4), v_{x, t+1}=\xi_{x, t+1}-\xi_{r, t+1}-\xi_{x, t+1}$. The component $\xi_{x, 1+1}$ can be interpreted as news about future inflation, while $\xi_{r, 1+1}$ is news about future real interest rates and $\xi_{x, 1+1}$ is news about future excess bond returns. The table reports the variances and covariances of these components, divided by the variance of $v_{x, t+1}$ so that the numbers reported add up to one. The bottom panel of the table gives the implied $R^{2}$ statistics from simple regressions of $v_{x, t+1}$ on eacli component. Asymplotic standard errors are reported in parentheses below eacli statistic in the table. 
Table 5: Correlations of Compononte of Bond and Stock Raturus

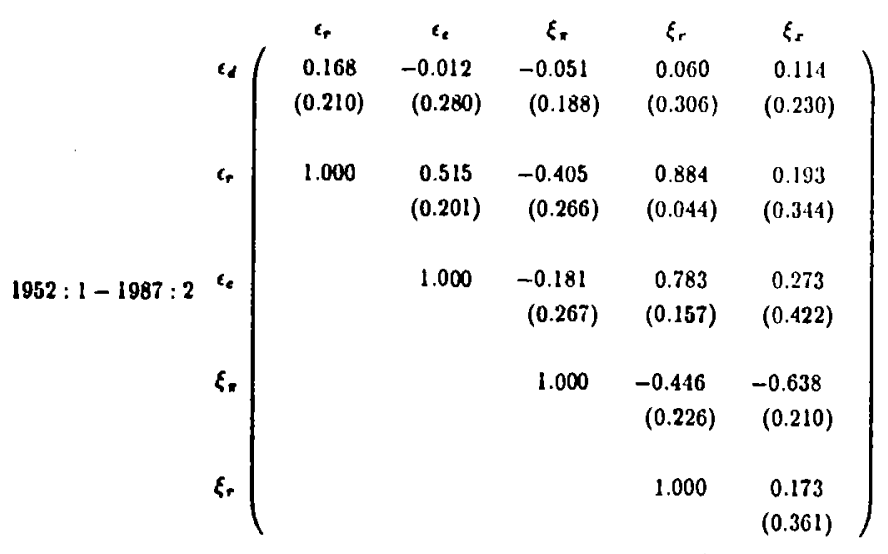

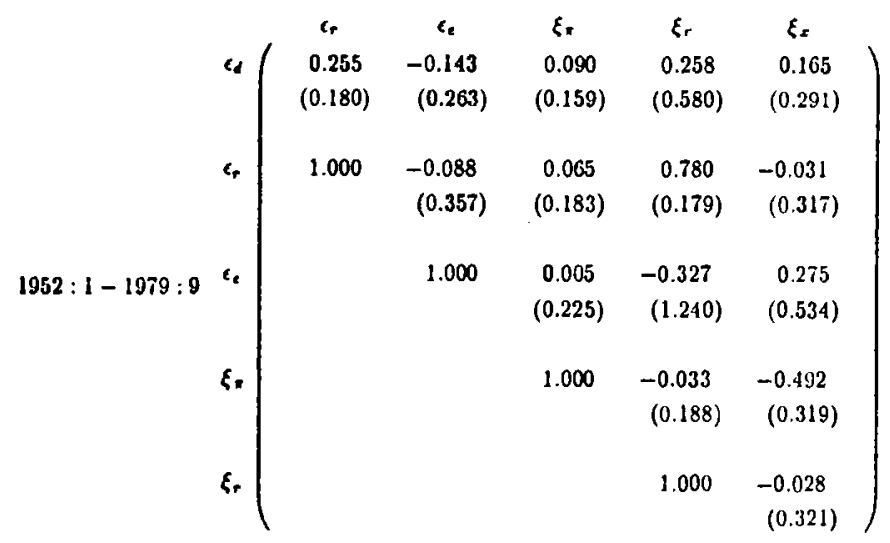




\begin{tabular}{|c|c|c|c|c|c|c|}
\hline & & $c_{r}$ & $c_{\mathrm{c}}$ & $\xi_{\pi}$ & $\xi_{r}$ & $\xi_{x}$ \\
\hline & $c_{d}$ & 0.334 & -0.234 & 0.342 & 0.514 & 0.142 \\
\hline & & $(0.245)$ & $(0.170)$ & $(0.182)$ & $(0.260)$ & $(0.469)$ \\
\hline & $c_{r}$ & 1.000 & -0.108 & 0.418 & 0.567 & 0.138 \\
\hline & & & $(0.323)$ & $(0.180)$ & $(0.286)$ & $(0.548)$ \\
\hline $1952: 1-1972: 12$ & $c_{\bullet}$ & & 1.000 & 0.176 & -0.211 & 0.036 \\
\hline & & & & $(0.213)$ & $(0.493)$ & $(0.561)$ \\
\hline & $\xi_{\pi}$ & & & 1.000 & 0.330 & -0.272 \\
\hline & & & & & $(0.206)$ & $(0.612)$ \\
\hline & $\xi_{r}$ & & & & 1.000 & 0.157 \\
\hline & & & & & & $(0.561)$ \\
\hline
\end{tabular}

\begin{tabular}{|c|c|c|c|c|c|c|}
\hline & $c_{r}$ & $\epsilon_{\varepsilon}$ & $\xi_{\pi}$ & $\xi_{r}$ & $\xi_{x}$ \\
\hline & & 0.581 & 0.536 & -0.359 & 0.581 & 0.243 \\
\hline & $c_{d}$ & $(0.230)$ & $(0.282)$ & $(0.277)$ & $(0.262)$ & $(0.374)$ \\
\hline & \multirow[t]{2}{*}{$\epsilon_{r}$} & 1.000 & 0.667 & -0.477 & 0.965 & 0.165 \\
\hline & & & $(0.207)$ & $(0.336)$ & $(0.022)$ & $(0.492)$ \\
\hline \multirow{4}{*}{$1973: 1-1987: 2$} & \multirow{2}{*}{$\epsilon_{e}$} & & \multirow[t]{2}{*}{1.000} & -0.313 & 0.775 & 0.359 \\
\hline & & & & $(0.335)$ & $(0.210)$ & $(0.478)$ \\
\hline & \multirow[t]{2}{*}{$\xi \pi$} & & & \multirow[t]{2}{*}{1.000} & -0.482 & -0.684 \\
\hline & & & & & $(0.343)$ & $(0.240)$ \\
\hline & \multirow[t]{2}{*}{$\xi_{r}$} & & & & 1.000 & 0.136 \\
\hline & & & & & & $(0.508)$ \\
\hline
\end{tabular}

Notes: This table is based on a monthly 1-lag VAR that includes the excess stock return, real interest rate, change in the 1 -month bill rate, 10-year and 2 -month yield spreads, log dividend-price ratio, and relative bill rate (the diference between the bill rate and a 1-year backwards moving average). The VAR is used to calculate the components of the unexpected excess stock return $v_{e, t+1}$ in equation (2.2), $v_{e, t+i}=$ $\epsilon_{d, t+1}-\epsilon_{r, t+1}-\epsilon_{e, t+1}$. The component $\epsilon_{d, t+1}$ can be interpreted as news about future dividends, while $\epsilon_{r, t+1}$ is news about future real interest rates and $\epsilon_{e, t+1}$ is news about future excess stock returns. The VAR is also used to calculate the components of the unexpected bond return $v_{x, i+1}$ in equation (2.4), $v_{x, t+1}=\xi_{\pi, t+1}-\xi_{r, t+1}-\xi_{x, 1+1}$. The component $\xi_{\pi, t+1}$ can be interpreted as news about future inflation, while $\xi_{r, t+1}$ is news about future real interest rates and $\xi_{x, t+1}$ is news about future excess bond returns. The table reports the correlations of these components, with asymptotic standard errors in parentleses. 
Table 6: Covariance Decomposition for Bond and Stock Returus

\begin{tabular}{|c|c|c|c|c|c|}
\hline $\begin{array}{l}\text { VAR lag length } \\
\text { Sample period }\end{array}$ & $\frac{1}{52: 1-87: 2}$ & $\begin{array}{c}1 \\
52: 1-79: 9\end{array}$ & $\frac{1}{52: 1-72: 12}$ & $\frac{1}{73: 1-87: 2}$ & $\begin{array}{c}3 \\
52: 1-87: 2\end{array}$ \\
\hline $\operatorname{Cov}\left(v_{a}, v_{x}\right)$ & 0.280 & 0.145 & -0.252 & 0.968 & 0.475 \\
\hline $\operatorname{Cov}\left(v_{e}, \xi_{\pi}\right)$ & $\begin{array}{c}2.962 \\
(3.858)\end{array}$ & $\begin{array}{c}0.235 \\
(1.653)\end{array}$ & $\begin{array}{c}-0.013 \\
(1.150)\end{array}$ & $\begin{array}{c}7.442 \\
(8.663)\end{array}$ & $\begin{array}{c}3.149 \\
(3.595)\end{array}$ \\
\hline $\operatorname{Cov}\left(v_{c}, \xi_{r}\right)$ & $\begin{array}{c}-1.038 \\
(0.565)\end{array}$ & $\begin{array}{c}0.100 \\
(0.443)\end{array}$ & $\begin{array}{c}0.201 \\
(0.346)\end{array}$ & $\begin{array}{c}-2.699 \\
(1.421)\end{array}$ & $\begin{array}{l}-1.088 \\
(0.625)\end{array}$ \\
\hline $\operatorname{Cov}\left(v_{e}, \xi_{x}\right)$ & $\begin{array}{c}-2.205 \\
(3.457)\end{array}$ & $\begin{array}{c}-0.481 \\
(1.587)\end{array}$ & $\begin{array}{c}0.063 \\
(1.133)\end{array}$ & $\begin{array}{c}-5.711 \\
(7.834)\end{array}$ & $\begin{array}{c}-2.537 \\
(3.240)\end{array}$ \\
\hline $\operatorname{Cov}\left(v_{x}, \epsilon_{d}\right)$ & $\begin{array}{c}-0.163 \\
(0.771)\end{array}$ & $\begin{array}{c}-0.547 \\
(0.423)\end{array}$ & $\begin{array}{c}-1.309 \\
(0.812)\end{array}$ & $\begin{array}{c}1.085 \\
(1.486)\end{array}$ & $\begin{array}{c}0.013 \\
(0.602)\end{array}$ \\
\hline $\operatorname{Cov}\left(v_{x}, \epsilon_{r}\right)$ & $\begin{array}{c}0.407 \\
(0.292)\end{array}$ & $\begin{array}{c}-0.051 \\
(0.092)\end{array}$ & $\begin{array}{c}-0.235 \\
(0.155)\end{array}$ & $\begin{array}{c}1.273 \\
(0.827)\end{array}$ & $\begin{array}{c}0.440 \\
(0.308)\end{array}$ \\
\hline $\operatorname{Cov}\left(v_{x}, \epsilon_{c}\right)$ & $\begin{array}{c}-0.850 \\
(0.938)\end{array}$ & $\begin{array}{c}-0.642 \\
(0.514)\end{array}$ & $\begin{array}{c}-0.822 \\
(0.849)\end{array}$ & $\begin{array}{r}-1.156 \\
(1.912)\end{array}$ & $\begin{array}{c}-0.901 \\
(0.858)\end{array}$ \\
\hline
\end{tabular}

Notes: This table is based on a monthly VAR that includes the excess stock return, real interest rate, change in the 1-month bill rate, 10 -year and 2 -month yield spreads, log dividend-price ratio, and relative bill rate (the difference between the bill rate and a 1-year backwards moving average). The VAR is used to calculate the components of the unexpected excess stock return $v_{c, t+1}$ in equation $(2.2), v_{e, t+1}=\epsilon_{d, t+1}-\epsilon_{r, t+1}-\varepsilon_{e, t+1}$. The component $\epsilon_{d, t+1}$ can be interpreted as news about future dividends, while $\epsilon_{r, t+1}$ is news about futurc real interest rates and $\epsilon_{c, 1+1}$ is news about future excess stock returns. The VAR is also used to calculate the componerts of the unexpected bond return $v_{x, t+1}$ in equation $(2.4), v_{x, t+1}=\xi_{x, t+1}-\xi_{r, t+1}-\xi_{x, c+1}$. The component $\xi_{\pi, t+1}$ can be interpreted as news about future inflation, while $\xi_{r, t+1}$ is news about future real interest rates and $\xi_{x, 1+1}$ is news about future excess bond returns. The table reports the covariance of the unexpected stock (bond) return with the components of the unexpected bond (stock) return. Asymptotic standard errors are given in parentlieses. 
Table 7: Variance Decouposition for Excess Level Portfolio Returns

\begin{tabular}{|c|c|c|c|c|c|}
\hline $\begin{array}{l}\text { VAR lag length } \\
\text { Sample period }\end{array}$ & $\begin{array}{c}1 \\
52: 1-87: 2\end{array}$ & $\begin{array}{c}1 \\
52: 1-79: 9\end{array}$ & $\frac{1}{52: 1-72: 12}$ & $\frac{1}{73: 1-87: 2}$ & $\begin{array}{c}3 \\
52: 1-87: 2\end{array}$ \\
\hline $\begin{array}{l}\text { Return } R^{2} \\
\text { Significance }\end{array}$ & $\begin{array}{l}0.127 \\
0.000\end{array}$ & $\begin{array}{l}0.181 \\
0.000\end{array}$ & $\begin{array}{l}0.298 \\
0.000\end{array}$ & $\begin{array}{l}0.096 \\
0.009\end{array}$ & $\begin{array}{l}0.206 \\
0.000\end{array}$ \\
\hline Sliares of: & & & & & \\
\hline $\operatorname{Var}\left(\lambda_{x}\right)$ & $\begin{array}{c}4.806 \\
(1.590)\end{array}$ & $\begin{array}{c}3.128 \\
(1.578)\end{array}$ & $\begin{array}{c}1.351 \\
(1.032)\end{array}$ & $\begin{array}{c}4.825 \\
(1.445)\end{array}$ & $\begin{array}{c}3.318 \\
(1.245)\end{array}$ \\
\hline $2 \operatorname{Cov}\left(\lambda_{x}, \lambda_{r}\right)$ & $\begin{array}{c}-7.638 \\
(3.034)\end{array}$ & $\begin{array}{r}-3.940 \\
(2.740)\end{array}$ & $\begin{array}{r}-0.974 \\
(1.581)\end{array}$ & $\begin{array}{r}-7.797 \\
(2.718)\end{array}$ & $\begin{array}{l}-4.644 \\
(2.264)\end{array}$ \\
\hline $\operatorname{Var}\left(\lambda_{r}\right)$ & $\begin{array}{c}3.833 \\
(1.488)\end{array}$ & $\begin{array}{c}1.812 \\
(1.240)\end{array}$ & $\begin{array}{c}0.623 \\
(0.675)\end{array}$ & $\begin{array}{c}3.972 \\
(1.343)\end{array}$ & $\begin{array}{c}2.327 \\
(1.084)\end{array}$ \\
\hline$R^{2}\left(\lambda_{\pi}\right)$ & $\begin{array}{c}0.203 \\
(0.098)\end{array}$ & $\begin{array}{c}0.429 \\
(0.208)\end{array}$ & $\begin{array}{c}0.553 \\
(0.312)\end{array}$ & $\begin{array}{c}0.178 \\
(0.092)\end{array}$ & $\begin{array}{c}0.299 \\
(0.141)\end{array}$ \\
\hline$R^{2}\left(\lambda_{r}\right)$ & $\begin{array}{c}0.000 \\
(0.002)\end{array}$ & $\begin{array}{c}0.014 \\
(0.062)\end{array}$ & $\begin{array}{c}0.030 \\
(0.166)\end{array}$ & $\begin{array}{c}0.001 \\
(0.009)\end{array}$ & $\begin{array}{c}0.000 \\
(0.001)\end{array}$ \\
\hline
\end{tabular}

Notes: This table is based on a monthly VAR tliat includes the excess stock return, real interest rate, change in the 1-month bill rate, 10-year and 2 -month yield spreads, log dividend-price ratio, and relative bill rate (the difference between the bill rate and a l-year backwards moving average). "Return $R^{2}$ " is the implied $R^{2}$ in a regression of the excess return on a "level portfolio" of 2-month bills on the VAR explanatory variables, while "Significance" is the joint significance of the explanatory variables in this regression. Tlie VAR is used to calculate the components of the unexpected level portfolio return $v_{l, t+1}$ in equation $(2,12)$, $v_{t, t+1}=-\lambda_{r, t+1}-\lambda_{r, t+1}$. The component $\lambda_{x, t+1}$ can be interpreted as news about future inflation, while $\lambda_{r, i+1}$ is news about future real interest rates. The table reports the variances and covariances of these components, divided by the variance of $v_{l, t+1}$ so that the numbers reported add up to one. The bottom panel of the table gives the implied $R^{2}$ statistics from simple regressions of $v_{t, t+1}$ on each component. Asymptotic standard errors are reported in parentheses below each statistic in the table. 
Table 8: Variance Decomposition for Excess Slope Portfolio Returus

\begin{tabular}{|c|c|c|c|c|c|}
\hline $\begin{array}{l}\text { VAR lag leiıgti } \\
\text { Sample period }\end{array}$ & $\begin{array}{c}1 \\
52: 1-87: 2\end{array}$ & $\frac{1}{52: 1-79: 9}$ & $\begin{array}{c}1 \\
52: 1-72: 12\end{array}$ & $\begin{array}{c}1 \\
73: 1-87: 2\end{array}$ & $\begin{array}{c}3 \\
52: 1-87: 2\end{array}$ \\
\hline $\begin{array}{l}\text { Return } R^{2} \\
\text { Siguificance }\end{array}$ & $\begin{array}{l}0.178 \\
0.000\end{array}$ & $\begin{array}{l}0.206 \\
0.000\end{array}$ & $\begin{array}{l}0.301 \\
0.000\end{array}$ & $\begin{array}{l}0.163 \\
0.000\end{array}$ & $\begin{array}{l}0.276 \\
0.000\end{array}$ \\
\hline \multicolumn{6}{|l|}{ Shares of: } \\
\hline $\operatorname{Var}\left(\mu_{\pi}\right)$ & $\begin{array}{c}4.932 \\
(1.547)\end{array}$ & $\begin{array}{c}3.040 \\
(1.631)\end{array}$ & $\begin{array}{c}1.157 \\
(0.983)\end{array}$ & $\begin{array}{c}4.743 \\
(1.159)\end{array}$ & $\begin{array}{c}2.406 \\
(1.201)\end{array}$ \\
\hline $2 \operatorname{Cov}\left(\mu_{\pi}, \mu_{r}\right)$ & $\begin{array}{c}-9.397 \\
(3.288)\end{array}$ & $\begin{array}{r}-4.487 \\
(2.992)\end{array}$ & $\begin{array}{c}-1.164 \\
(1.614)\end{array}$ & $\begin{array}{c}-9.504 \\
(2.584)\end{array}$ & $\begin{array}{c}-5.034 \\
(2.509)\end{array}$ \\
\hline $2 \operatorname{Cov}\left(\mu_{x}, \mu_{x}\right)$ & $\begin{array}{c}0.552 \\
(0.428)\end{array}$ & $\begin{array}{c}0.333 \\
(0.325)\end{array}$ & $\begin{array}{c}0.257 \\
(0.259)\end{array}$ & $\begin{array}{c}0.676 \\
(0.637)\end{array}$ & $\begin{array}{c}0.590 \\
(0.535)\end{array}$ \\
\hline $\operatorname{Var}\left(\mu_{r}\right)$ & $\begin{array}{c}4.858 \\
(1.759)\end{array}$ & $\begin{array}{c}2.095 \\
(1.421)\end{array}$ & $\begin{array}{c}0.657 \\
(0.714)\end{array}$ & $\begin{array}{c}5.130 \\
(1.513)\end{array}$ & $\begin{array}{c}2.961 \\
(1.362)\end{array}$ \\
\hline $2 \operatorname{Cov}\left(\mu_{r}, \mu_{r}\right)$ & $\begin{array}{c}-0.189 \\
(0.448)\end{array}$ & $\begin{array}{c}-0.029 \\
(0.264)\end{array}$ & $\begin{array}{c}0.050 \\
(0.235)\end{array}$ & $\begin{array}{c}-0.378 \\
(0.728)\end{array}$ & $\begin{array}{l}-0.230 \\
(0.634)\end{array}$ \\
\hline $\operatorname{Var}\left(\mu_{x}\right)$ & $\begin{array}{c}0.243 \\
(0.232)\end{array}$ & $\begin{array}{c}0.047 \\
(0.052)\end{array}$ & $\begin{array}{c}0.043 \\
(0.046)\end{array}$ & $\begin{array}{c}0.333 \\
(0.387)\end{array}$ & $\begin{array}{c}0.306 \\
(0.350)\end{array}$ \\
\hline$R^{2}\left(\mu_{\pi}\right)$ & $\begin{array}{c}0.053 \\
(0.061)\end{array}$ & $\begin{array}{c}0.305 \\
(0.199)\end{array}$ & $\begin{array}{c}0.428 \\
(0.324)\end{array}$ & $\begin{array}{c}0.023 \\
(0.051)\end{array}$ & $\begin{array}{c}0.014 \\
(0.057)\end{array}$ \\
\hline$R^{2}\left(\mu_{r}\right)$ & $\begin{array}{c}0.001 \\
(0.007)\end{array}$ & $\begin{array}{c}0.013 \\
(0.054)\end{array}$ & $\begin{array}{c}0.015 \\
(0.111)\end{array}$ & $\begin{array}{c}0.007 \\
(0.020)\end{array}$ & $\begin{array}{c}0.037 \\
(0.067)\end{array}$ \\
\hline$R^{2}\left(\mu_{x}\right)$ & $\begin{array}{c}0.742 \\
(0.129)\end{array}$ & $\begin{array}{c}0.840 \\
(0.396)\end{array}$ & $\begin{array}{c}0.895 \\
(0.261)\end{array}$ & $\begin{array}{c}0.698 \\
(0.214)\end{array}$ & $\begin{array}{c}0.773 \\
(0.170)\end{array}$ \\
\hline
\end{tabular}

Notes: This table is based on a monthly VAR that includes the excess stock return, real interest rate, change in the 1-inonth bill rate, 10-year and 2-month yield spreads, and the relative bill rate (the difference between the bill rate and a 1-year backwards moving average). "Return $R^{2 n}$ is the implied $R^{2}$ in a regression of the excess return on a "slope portfolio", long 10-year bonds and short 2-month bills, on the VAR explanatory variables, while "Significance" is the joint significance of the explanatory variables in this regression. The VAR is used to calculate the components of the unexpected slope port folio return $v_{m, t+1}$ in equation (2.12), $v_{m, 1+1}=-\mu_{x, 1+1}-\mu_{r, 1+1}-\mu_{x, 1+1}$. The component $\mu_{x, 1+1}$ can be interpreted as news about future inflation, while $\mu_{r, t+1}$ is news about future real interest rates and $\mu_{x, 1+1}$ is news about future excess bond returns. The table reports the variances and covariances of these components, divided by the variance of $v_{m, t+1}$ so that the numbers reported add up to one. The bottom panel gives the implied $R^{2}$ statistics from simple regressions of $v_{m, t+1}$ on each component. Asymptotic standard errors are reported in parentlieses below each statistic in the table. 
Table 9: Correlations of Components of Level and Slope Portfolio Returas

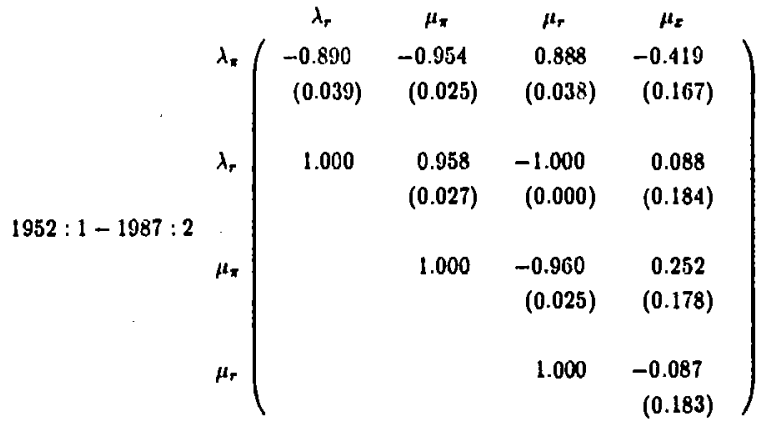

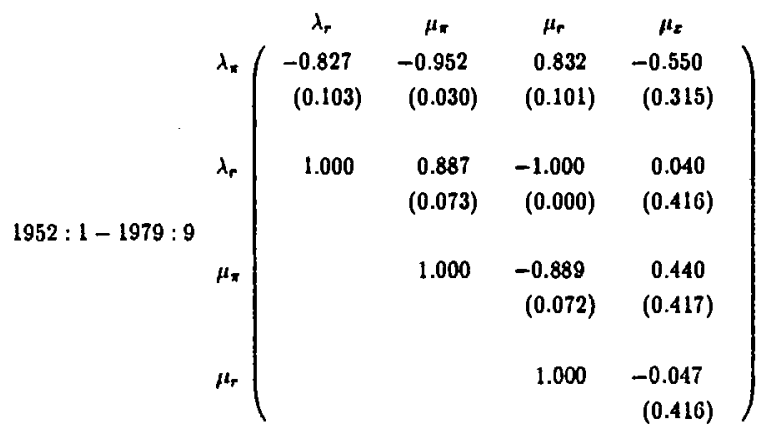

CONTINUED ON NEXT PAGE 


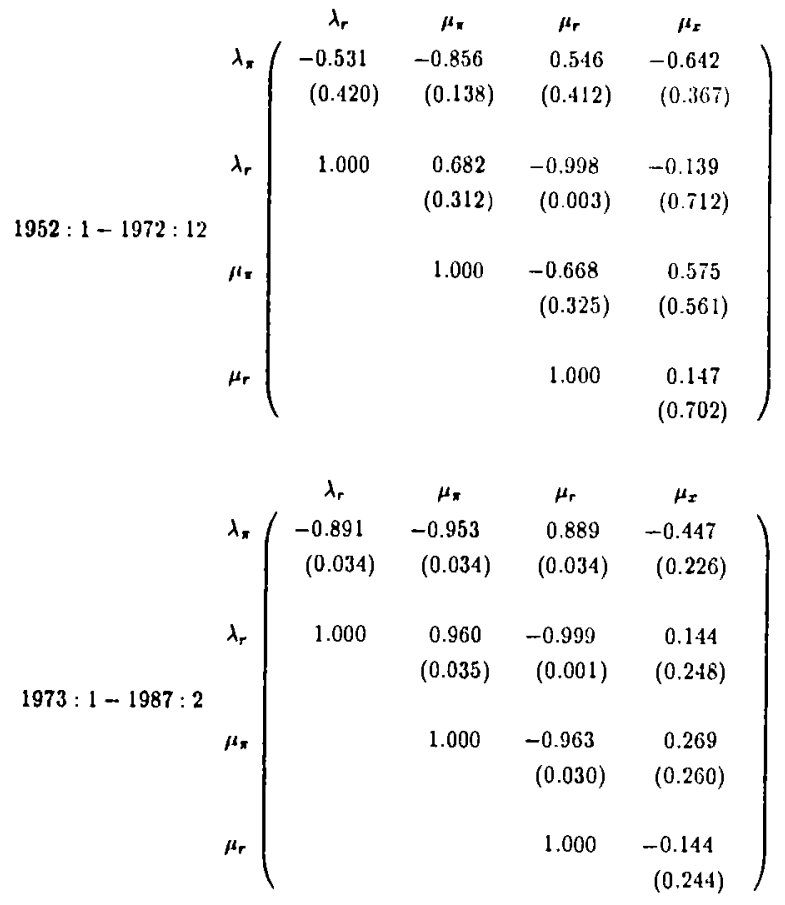

Notes: This table is based on a monthly 1-lag VAR that includes tle excess stock return, real interest rate, change in the 1-month bill rate, 10-year and 2-month yield spreads, log dividend-price ratio, and relative bill rate (the difference between the bill rale and a l-year backwards moving average). The VAR is used to calculate the components of the unexpected return on a "level portfolio" (long 2-month bills) $v_{i, t+1}$ in equation (2.12), $v_{t, t+1}=-\lambda_{r, t+1}-\lambda_{r, t+1}$. The component $\lambda_{\pi, t+1}$ can be interpreled as news about future inflation, while $\lambda_{r, t+1}$ is news about future real interest rates. The VAlR is also used to calculate the components of the unexpected return on a "slope portfolio" (long 10-year bonds, sliort 2-month bills) $v_{m, t+1}$ in equation (2.12), $v_{m, t+1}=-\mu_{x, t+1}-\mu_{r, t+1}-\mu_{x, t+1}$. The component $\mu_{x, t+1}$ can be interpreted as news about future inflation, while $\mu_{r, t+1}$ is news about future real interest rates and $\mu_{x, t+1}$ is news about future exeess bond returns. The table reports the correlations of these components, witl asymptotic standard errore in parentheses. 